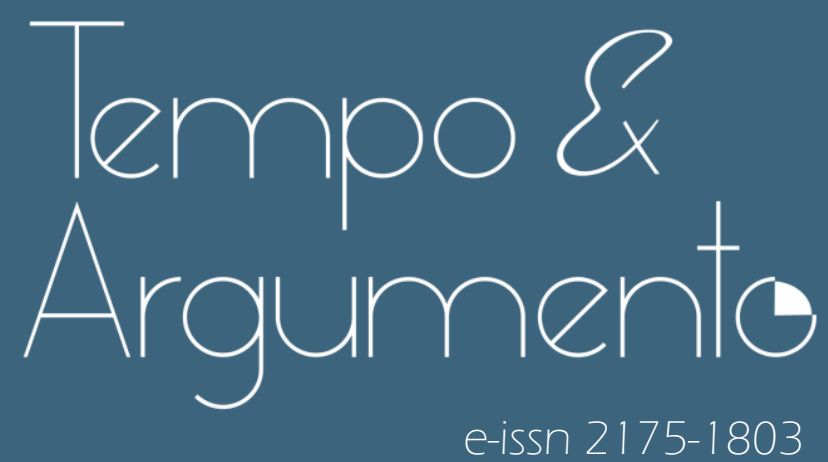

\title{
Manuais didáticos em questão: propostas de ensino da História da América (1971 e 2011 )
}

• Miriã Lúcia Luiz

Doutora em Educação pela Universidade Federal do Espirito Santo (UFES).

Professora da Universidade Federal do Espírito Santo (UFES).

Vitória, ES - BRASIL

lattes.cnpq.br/2276583662907573

mirialuiz@gmail.com

(D) orcid.org/0000-0001-6825-1541

- Rosianny Campos Berto

Doutora em Educação pela Universidade Federal do Espírito Santo (UFES).

Professora da Universidade Federal do Espírito Santo (UFES).

Vitória, ES - BRASIL

lattes.cnpq.br/7265885791648266

rosiannyb@gmail.com

(D) orcid.org/0000-0003-3143-3258

Para citar este artigo:

LUIZ, Miriă Lúcia; BERTO, Rosianny Campos. Manuais didáticos em questão: propostas de ensino da História da América ( 1971 e 201 1). Tempo e Argumento, Florianópolis, v. 13, n. 32, e0205, jan./abr. 2021

doi) http://dx.doi.org/10.5965/2175180313322021 e0205

Recebido: 10/04/2020

Aprovado: 26/10/2020 


\title{
Manuais didáticos em questão: propostas de ensino da História da América (1971 e 2011)
}

\begin{abstract}
Resumo
Analisa diferentes propostas para o ensino/aprendizagem de conteúdos de História da América presentes em dois manuais didáticos: o Cadernos MEC: História da América (1971) e História Geral e do Brasil (2011). A análise orienta-se pelo método regressivo (BLOCH, 2001), em busca de permanências e descontinuidades nas disciplinas escolares, de modo geral, e no Ensino de História, em particular. Além do intervalo de quarenta anos entre as publicações, os manuais se distanciam quanto aos aspectos pedagógicos e historiográficos: o Cadernos MEC: História da América varia entre indícios do ideário escolanovista e de uma perspectiva tradicional, com atividades pautadas no método mnemônico; a obra didática de Vicentino e Dorigo (2011) compõe-se de atividades que favorecem a autonomia intelectual dos estudantes, o que indica uma adequação do conteúdo pedagógico a princípios neoliberais, ao privilegiar o protagonismo de cada estudante em seu processo de aprendizagem. Quanto à concepção de História, o manual de 1971 apresenta algumas feições positivistas, com centralidade em datas e fatos de personagens de uma história predominantemente política. Na seção assessoria pedagógica da obra de 2011 há referências com possíveis interpretações derrotistas da América Espanhola, com foco na exploração e violência dos "vencedores sobre os vencidos", contudo, os exercícios se alinham aos pressupostos da Nova História, o que permite a elaboração do conhecimento histórico pelos estudantes, por meio da análise interna e externa de fontes iconográficas, da interpretação de textos historiográficos e da multiplicidade de abordagens e de fontes históricas. Compreender quais sujeitos têm lugar nas expectativas curriculares é escolha crucial para a composição da tapeçaria a ser tecida pelo historiador (GINZBURG, 2007), mas também ajuda a pensar o papel dos manuais didáticos, como produtos que são, carregados de intenções.
\end{abstract}

Palavras-chave: História - Estudo e Ensino. América Espanhola - História. Ensino de História.

\section{Teaching manuals in question: proposals for teaching the History of America (1971 and 2011)}

\begin{abstract}
This article analyzes different proposals for teaching/learning contents on the history of America from two teaching manuals: Cadernos MEC: History of America (1971) and General History and Brazil (2011). The analysis is guided by the regressive method (BLOCH, 2001), in search of permanence and discontinuities in school subjetcs, in general, and History Teaching, in particular. Besides the forty-year interval between publications, the manuals distance themselves on pedagogical and historiographic aspects: Cadernos MEC: History of America varies between indications of New School ideas and a traditional perspective is linked to a traditional pedagogical perspective, with activities based on the mnemonic method; the didactic work of Vincentino and Dorigo (2011) consists of activities that favor the intellectual autonomy of students, which indicates an adaptation of the pedagogical content to neoliberal principles, by privileging the role of each student in their learning process. As for the conception of History, the 1971 manual presents positivist features, centered in dates and facts of characters from a predominantly political history. In the section pedagogical advisory of the 2011 work there are references with possible defeatist interpretations of the Spanish America, focusing on the exploration and violence of the "winners over the losers"; however, the exercises align with assumptions of the New History, which allows the elaboration of historical knowledge by students, through internal and external analysis of iconographic sources, the interpretation of historiographic texts, and the multiplicity of approaches and historical sources. Understanding which subjects take place in curricular expectations is a crucial choice for the composition of the tapestry to be woven by the historian (GINZBURG, 2007), but it also helps to think about the role of teaching manuals, such as the products they are, loaded with intentions.
\end{abstract}

Keywords: History - Study and Teaching. Spanish America - History. History Teaching. 


\section{Introdução}

A História, em perspectiva ampla, como narrativa historiográfica e, de modo particular, como disciplina escolar, tem se constituído por processos permeados de conflitos e controvérsias, configurando-se, como bem lembrou Laville (1999), como uma “Guerra de Narrativas”. Na produção historiográfica do ensino de História no Brasil, não são raros os momentos em que esse campo disciplinar assume centralidade em reformas educacionais - como as Reformas Francisco Campos, em 1931, e Gustavo Capanema, em 1942 - e em mudanças curriculares - como as ocorridas com a Lei no 5.692/71, que instituiu a obrigatoriedade dos Estudos Sociais em todo o 1o grau, substituindo a História e a Geografia, bem como com a publicação dos Parâmetros Curriculares Nacionais (PCNs), nas décadas de 1990 e 2000, que marcou a reconstrução da História como código disciplinar¹.

Como parte indissociável dessas relações de força (GINZBURG, 2002), por meio das quais as narrativas passam a compor o repertório da História, não podem ser negligenciados os manuais e os livros didáticos produzidos e veiculados nas escolas, pois são dispositivos nos quais cada peça dessa narrativa é cuidadosamente selecionada (LAVILLE, 1999).

Os processos segundo os quais a História se constituiu como disciplina escolar nos instigam a interrogar sobre as narrativas que compõem esse campo disciplinar, em busca de compreender quais conteúdos são contemplados, quem os determina, quais os critérios de sua seleção, quem os institui, e com quais objetivos eles são selecionados. Responder a essas questões requer uma reflexão sobre a historicidade dessa disciplina no Brasil, no início do século XIX, pois é no período pós-independência que a História se constitui como código disciplinar e, a partir daí, dá-se início à escrita de uma História Nacional que será

\footnotetext{
Schmidt (2012) conceitua código disciplinar a partir da teorização do espanhol Fernandez Cuesta, para quem o processo de constituição do código disciplinar relaciona-se à construção do processo de escolarização e de formação da cultura escolar. Ao processo de "didatização" que ocorre entre a ciência de referência e a ciência escolar, implica na produção do que ele chama de "textos visíveis do código disciplinar", tais como currículos e manuais didáticos, além dos "textos invisíveis do código disciplinar", isto é, as práticas dos professores e dos alunos em aulas de História (SCHMIDT, 2012).
} 
tomada como modelo para a constituição da Nação e que, portanto, deveria ser legitimada, consolidando uma identidade nacional².

O modelo quadripartite - História Antiga, Média, Moderna e Contemporânea - tem ocupado a centralidade dos currículos das escolas brasileiras desde que a História da Civilização se separou, definitivamente, da História Sagrada, nas primeiras décadas do século XX. Bittencourt (2005) assinala tentativas fracassadas de inserção da História da América nas prescrições curriculares para fortalecer a formação da identidade latino-americana e para forjar projetos políticos nacionais, já que a História do Brasil se constituía em apêndice. Testemunhamos, assim, pela via da literatura da área, que nas disputas pelas narrativas historiográficas que devem compor os currículos de História, a História nacional e a História da América têm sido negligenciadas.

Diante disso, como forma de compreender o lugar que os temas relativos à História da América têm ocupado nos manuais didáticos brasileiros de História, especialmente naqueles que são avaliados e veiculados por órgãos nacionais, este texto objetiva analisar duas diferentes propostas para o ensino/aprendizagem de conteúdos relativos à história da América, presentes em manuais didáticos destinados ao segundo grau/ensino médio ${ }^{3}$ e publicados num intervalo de quarenta anos: o primeiro em 1971 e o segundo em 2011. Nossa intenção é investigar o modo como, historicamente, os manuais didáticos têm proposto o ensino desse conteúdo.

As fontes selecionadas para esta análise são: o Cadernos MEC: História da América, que teve sua primeira edição publicada em 1971 pelo Ministério da Educação e Cultura (MEC), por meio da Fundação Nacional de Material Escolar (Fename), e o livro didático História Geral e do Brasil, publicado no ano de 2011 pela Editora Scipione e constante da lista de avaliações do Plano Nacional do Livro Didático (PNLD) nos anos de 2012 e 2015. Ambos os manuais foram produzidos para atender ao segundo grau/ensino médio. Assim, a escolha dessas

\footnotetext{
2 Sobre o tema, ver: Fonseca, T. (2003); Bittencourt (2009); Schmidt (2012).

3 A mudança na organização e denominação do sistema de ensino ocorre a partir da Lei de Diretrizes e Bases da Educação Nacional no 9394/96. A educação básica passa a compreender a educação infantil (com duração de 4 anos: creche: 0 a 3 anos); Pré-escola (4 a 6 anos); Ensino fundamental, com duração de 8 anos (7 a 14 anos); Ensino Médio, com duração de 3 anos (15 a 17 anos) e superior, com duração variável (acima de 17 anos) (BRASIL, 1996, art. 4).
} 
fontes justifica-se por fazerem parte de conjuntos de manuais propostos e distribuídos pelo Governo Federal e, também, por conterem atividades destinadas aos estudantes do ensino médio, dentro dos conteúdos de história da América.

A análise orienta-se pelas proposições de Bloch (2001), especificamente sobre suas problematizações acerca do método regressivo, que propõe compreender o presente pelo passado e, correlativamente, o passado pelo presente, de modo que analisar obras separadas temporalmente por quarenta anos pode oferecer indícios para compreensão de permanências e descontinuidades nas disciplinas escolares, como a História, tendo em vista as escolhas políticas que são feitas em torno dos conteúdos e do que se propõe como meios para abordá-los.

Consideramos, assim, que essas fontes precisam ser compreendidas a partir das relações de força (GINZBURG, 2002) que interferem/interferiram em sua produção e das intenções a que atendem. Na análise de um impresso, como é o caso do livro didático, cabe ainda lembrar que ele é sempre produto de estratégias e que, conforme orienta Certeau (2004), há uma distância entre aquilo que se propõe como prescrição e os usos que se faz do que é prescrito. Nesse caminho, o leitor ou aquele que recebe o livro didático, seja o professor, seja o aluno, inventa "[...] outra coisa que não aquilo que era a 'intenção' deles. Destacaos de sua origem (perdida ou acessória). Combina os seus fragmentos e cria algo não sabido no espaço organizado por sua capacidade de permitir uma pluralidade indefinida de significações" (CERTEAU, 2004, p. 264-265).

Pensando nas questões que essas ideias suscitam, os livros didáticos são analisados com base em três dimensões: a) como dispositivo textual e material e, portanto, como artefato cultural que confere legibilidade a determinadas formas de socializar o conhecimento; b) como recurso pedagógico, cuja finalidade é auxiliar o trabalho dos estudantes e dos professores, e que carrega em si determinadas intenções; e c) como ferramenta de mediação do conhecimento histórico baseado em concepções teóricas que orientam a abordagem dos temas (BITTENCOURT, 2009). 
A escolha da História da América para esta análise justifica-se com base nas seguintes observações: a) por sua trajetória descontínua nos currículos escolares; e b) pelas lacunas nos estudos relativos ao ensino desse conteúdo. Sobre isso, Silva (2004) identificava, no início deste século, a escassez de textos que dessem lugar ao ensino de História da América no nível secundário e, apontava para a quase inexistência de discussões sobre o ensino dessa disciplina naquele contexto.

Os debates em torno da presença/ausência desse tema nos currículos escolares ganharam centralidade em discussões mais recentes sobre a Base Nacional Comum Curricular (BNCC), homologada em 20 de dezembro de 2018, cuja proposta pedagógica para o ensino de História tem sido amplamente questionada por enfatizar temas que partam de estudos da América, com foco no Brasil e no continente africano, em detrimento de uma história eurocêntrica. Aqui caberia outra e complexa discussão a respeito de qual narrativa histórica está contemplada na BNCC e se tal perspectiva possibilita romper com 0 etnocentrismo. Reis (2015), ao analisar a História da América na BNCC, provocanos a pensar se a simples exclusão da História europeia nos permitiria uma melhor compreensão da História do Brasil e da América. Sob sua ótica:

Excluir o conhecimento dos processos históricos europeus desde a antiguidade até o período da expansão ultramarina portuguesa (porque a ênfase é em Portugal) em lugar de gerar pensamento crítico capaz de analisar, desnudar e interpretar o eurocentrismo, nos deixará sem ferramentas para sua crítica. O que deve mudar é o ponto de vista. Não ficarmos cegos. Não devemos trocar um etnocentrismo por outro. (REIS, 2015, sem paginação)

Uma análise detalhada e criteriosa, especialmente da terceira versão do documento, homologada em 2018, é um exercício urgente para nós professores e pesquisadores da área, pois, segundo Moreno (2016), trata-se de um déjà vu e, paradoxalmente, aponta novos dilemas no século XXI. Isso nos remete à reação intensa da imprensa às propostas curriculares do estado de São Paulo, produzidas na década de 1980, com adjetivações do tipo 'barbarização ideológica', 'subversão', 'ignorância no poder', ‘ideologização do ensino'. Nos últimos cinco anos, em meio ao processo de produção da BNCC, vivemos 
situações similares com a emergência de discursos de viés antidemocrático, além do impedimento das discussões das questões de sexualidade e gênero nas escolas, a presença e a atuação de movimentos e slogans como o Escola Sem Partido ${ }^{4}$, que, semelhantemente aos antigos ideais da Doutrina de Segurança Nacional, busca interditar as discussões políticas e sociais em sala de aula (REIS, 2015).

Em meio a tais problemáticas, também pertinentes à reflexão sobre a História ensinada nas escolas, situamos a discussão deste artigo nos contornos assumidos pela História da América nos manuais didáticos. Poderíamos questionar o lugar que ela ocupa na escola, como é abordada, que sentidos tem esse conhecimento para estudantes brasileiros do Ensino Médio.

Assim, um olhar mais aprofundado para as fontes - Cadernos MEC: História da América e História Geral e do Brasil - pode contribuir para a identificação dos conteúdos que são/foram abordados no nível de ensino em questão e para o exame daquilo que se espera que os alunos do Ensino Médio conheçam sobre o tema, e quais elaborações podem ser feitas pelos estudantes ao realizarem as atividades propostas. Para isso, partimos do entendimento de que o conhecimento histórico a ser socializado na escola precisa ter sentido para os sujeitos. Daí uma análise que permita compreender se as propostas em questão possibilitam a produção do saber histórico escolar.

\section{O Livro didático e o ensino de História da América}

No processo de constituição da História como disciplina escolar, iniciado no século XIX (BITTENCOURT, 2009; FONSECA, T., 2003; SCHMIDT, 2012), os livros didáticos têm se configurado como ferramentas inerentes à prática pedagógica do professor e aos trabalhos escolares dos estudantes. Assim, entendidos como objetos culturais de difícil definição (BITTENCOURT, 2009), os manuais didáticos

\footnotetext{
${ }^{4}$ Trata-se do Projeto de Lei no 7180/14, em tramitação na Câmara dos Deputados, que propõe alterações na Lei no 9.394/96, com vistas a obrigar as escolas ao: "[...] respeito às convicções do aluno, de seus pais ou responsáveis, tendo os valores de ordem familiar precedência sobre a educação escolar nos aspectos relacionados à educação moral, sexual e religiosa, vedada a transversalidade ou técnicas subliminares no ensino desses temas obrigar" (BRASIL, 2014).
} 
foram constituídos, historicamente, como importante recurso para a educação básica.

Ao tematizar essa história, Cury (2009) remonta ao processo de colonização e informa que o livro didático chegou ao Brasil em 1549, com os jesuítas, na expedição de Tomé de Souza, que trouxe livros escolares para o ensino da leitura e da escrita nos colégios criados ao lado das igrejas. Com sua expulsão, em 1759, esses manuais foram esquecidos.

Mais tarde, no início do século XIX, esse material, que começava a ser usado com maior ênfase nas escolas, seguia modelos estrangeiros, especialmente o francês. A partir do século XX, com a expansão do sistema escolar, começou a ganhar feições mais brasileiras, com base em propostas de nacionalização da literatura escolar e do incremento visual por meio de um número maior de imagens (BITTENCOURT, 2009). Tratava-se de manuais que ora ofereciam ao professor acesso a teorias pedagógicas, ora dispunham de ferramentas a serem usadas nas aulas, o que Carvalho (2006) denominou caixa de utensílios ${ }^{5}$, ao compreender esses impressos como materiais capazes de

[...] fornecer ao professor 'coisas para usar' na sala de aula, compondo um programa curricular: uma poesia aqui, um canto ali, uma estorinha lá. Nessa lógica, o Manual é composto como impresso cujos usos supõem regras que não necessitam de explicitação, sendo dadas como regras culturalmente compartilhadas. (CARVALHO, 2006, sem paginação)

Entre finais do século XIX e as décadas iniciais do século XX, a lógica que orientava a produção desse tipo de material relacionava-se com o campo normativo das concepções pedagógicas em circulação, segundo as quais, a "boa arte de ensinar" pautava-se na "boa cópia de modelos". Assim, também, os códigos de leitura desse material vinculavam-se à crença no impacto renovador das novas propostas pedagógicas.

Ainda que a organização de um programa de avaliação desses livros seja algo relativamente recente, as políticas públicas para o livro didático começaram

\footnotetext{
${ }^{5}$ Ao analisar alguns Manuais de Pedagogia em circulação no Brasil, entre o final do século XIX e as primeiras décadas do século XX, Carvalho (2006) os compreende com base em dois modelos de configuração material dos impressos que eram produzidos para o uso de professores: a caixa de utensílios e o tratado de pedagogia.
} 
a ser pensadas ainda no Estado $\mathrm{Novo}^{6}$, quando foi instituída uma Comissão Nacional de Livros Didáticos que determinavam regras para produção, compra e até mesmo utilização desse material. Segundo Miranda e Luca,

Naquele contexto, a despeito da diversidade de projetos políticos e culturais, reservava-se à educação lugar privilegiado na formação da nacionalidade, tarefa assumida pelo Ministério da Educação e Saúde, que não descuidou do controle do material educativo utilizado pela população escolar. Nesse sentido, a educação constituiu-se em veículo privilegiado para introdução de novos valores e modelagem de condutas, sobretudo com base nos mecanismos prescritivos no campo do currículo e do material instrucional, dentre os quais o livro didático emergia como peça ideológica fundamental, que desempenha importante papel estratégico na difusão dos valores apregoados pelo regime. (MIRANDA; LUCA, 2004, p. 124-125)

Oficialmente, o livro didático ganhou espaço nas políticas em 1937, com a criação do Instituto Nacional do Livro (INL) ${ }^{7}$, iniciativa de Gustavo Capanema. O que se seguiu a partir daí foi uma série de políticas que interfeririam na sua produção e distribuição. Entre elas, é possível citar: a criação da Campanha do Livro Didático e Manuais de Ensino (Caldeme), em 1952, por Anísio Teixeira; a realização da Campanha Nacional de Material Escolar (CNME), entre 1956 e 1967 e da Fundação Nacional de Material de Ensino (Fename), de 1967 a 1983; a criação, em 1966, da Comissão do Livro Técnico e do Livro Didático (Colted), pelo Governo Castello Branco; e a criação do PNLD $^{8}$, em 1985, para entrar em vigor a partir de 1986 (CURY, 2009).

Importa dizer, como lembra Munakata (2012, p. 184), que o livro didático é, na atual sociedade capitalista, um produto, uma mercadoria: "Não se pode abstrair do livro - e do livro didático - a determinação de que ele é, antes de tudo, produzido para o mercado" e esse mercado é a escola.

\footnotetext{
${ }^{6}$ Período entre 1937 e 1945, iniciado quando Getúlio Vargas institui um governo de exceção com apoio dos militares.

Esse órgão deveria editar obras literárias que fossem de interesse para formação cultural da população. Deveria, também, criar uma enciclopédia nacional, um dicionário próprio e expandir o número de bibliotecas. Ao final do Estado Novo, o INL passa a se responsabilizar pela publicação dos livros didáticos (CURY, 2009).

3 O PNLD teve como intenções: universalizar e melhorar o ensino de 10 grau, com base no Programa Educação para Todos; pretendia também promover a valorização do magistério, conferindo, por exemplo, ao professor, a possibilidade de participação na indicação do livro didático. Outro propósito era reduzir os gastos da família com a educação de seus filhos (CURY, 2009).
} 
Interessa-nos, também, compreender o livro didático na relação com o lugar que assume como objeto de investigação, especificamente, aquele relativo à disciplina História. Em 2003, Thaís Nivia Fonseca o situava como um dos principais temas de pesquisa da área, ao lado das formulações dos programas e das diretrizes curriculares. Nesse mesmo ano, Selva Fonseca, ao analisar publicações que tematizam o livro didático de História, indicava como delimitações dos estudos, os conteúdos nele veiculados, os significados de sua ampla utilização no Brasil e as formas alternativas ao uso desse material, que muitas vezes tem se tornado o elemento definidor do processo de ensino (FONSECA, S., 2003).

As autoras apontaram nos estudos duas tendências: a) o livro didático, em consonância com os currículos, como canal privilegiado para a difusão de determinados saberes históricos e; b) o pouco investimento em pesquisas dedicadas à apropriação do conteúdo do livro didático de História em contextos educativos.

Em estudo realizado em 2011, Bittencourt percorreu a trajetória das pesquisas sobre o livro didático de História de 1980 à primeira década do século XXI e observou uma mudança quanto aos preconceitos e ao desprestígio de que esse material era revestido naquela década, quando era considerado objeto limitado a divulgar uma ideologia das classes dominantes, caracterizando-se como produção de segunda classe e que, de alguma maneira, também desprestigiava aqueles que dele se ocupavam. Para a autora, o livro didático de História continua sendo objeto de variadas interpretações, condição que possibilita debates fecundos, especialmente ao dialogar com outras áreas, contribuindo para a ampliação dos referenciais historiográficos e para a inclusão de estudos comparados entre obras de diversos países.

São inegáveis, portanto, os avanços nas pesquisas sobre o livro didático no Brasil, o que é creditado, por Bittencourt (2011, p. 508), "[...] à proliferação de publicações nacionais e internacionais sobre a produção didática, com análises que têm possibilitado conhecer com maior profundidade a complexidade com que se reveste esse material didático - mercadoria e depositário de 
conhecimento curricular, formador de professor". Embora a autora tenha tradição em estudos sobre os livros didáticos de História no Brasil e, também, tematize a América em seus estudos, ao focalizar as trajetórias de pesquisas sobre a produção didática de História, não situa a presença (ou mesmo a ausência) do continente americano em tais produções. Isso aponta para duas evidências: a) o corpus documental - dissertações e teses publicadas entre 1980 e a primeira década do século XXI - não tematiza esse conteúdo; b) existem algumas lacunas nos currículos dos cursos de formação de professores, nos sistemas de educação básica e, ao que tudo indica, nos livros didáticos.

A partir disso, a constatação registrada por Fernandes e Moraes (2005) é um indício eloquente para pensarmos algumas dessas ausências. Ao analisar as imagens da história do continente latino-americano nos livros didáticos do Ensino Médio, os autores registram:

No que se refere à América hispânica, há pouco material traduzido para o português. Como nenhum dos autores analisados é especialista na área, há que inferir que leituras mais complexas e em outras línguas não poderiam ser feitas dentro do calendário de trabalho das editoras. Como resultado, os manuais escolares foram feitos sob a égide de livros de divulgação ou best-sellers panfletários. (FERNANDES; MORAIS, 2005, p. 145, grifo dos autores)

Ainda que Fernandes e Morais (2005) tenham delimitado sua análise em seis coleções didáticas, nos parece apropriada a problematização a respeito da produção do livro didático de História, de forma mais ampla, no que se refere ao conteúdo América hispânica, pois a escassez de material traduzido para o português nos parece ainda ser um problema ${ }^{9}$ e, tendo em vista o pouco espaço que esse conteúdo ocupa nos currículos dos cursos de licenciatura em História, ${ }^{10}$ bem como, nas elaborações curriculares mais recentes, ${ }^{11}$ parece-nos pouco provável que o número de autores de livros didáticos especializados no tema

\footnotetext{
9 Cabe destacar que a escassez de informações disponíveis sobre a recepção e circulação de manuais didáticos do início do século XX que tematizam América Espanhola é também um problema na Argentina, como aponta Marinho (2013).

${ }^{10}$ Como exemplo, no Projeto Pedagógico do Curso de História da Universidade Federal do Espírito Santo (UFES, 2018), a América Espanhola aparece apenas na ementa de uma disciplina obrigatória: História da América Colonial e de uma optativa: História das Ideias nas Américas I. ${ }^{11}$ No Currículo Básico da rede estadual do Espírito Santo para o Ensino Médio (2009), por exemplo, o tema América aparece em um dos conteúdos do 1o ano e em dois do 3o ano. Especificamente, a América Espanhola não é mencionada no documento.
} 
tenha aumentado. Com isso posto, além da escassez de abordagens sobre o assunto, interessa-nos entender o lugar ocupado pela América Espanhola nesse material, bem como, as razões pelas quais a estudamos, como a estudamos e como a estudávamos há alguns anos.

Os tópicos de História da América já estavam presentes nos programas e planos de ensino do Colégio Pedro II do Rio de Janeiro, no período Imperial, como indica Bittencourt (2005). Contudo, Urban e Schimdt (2014) informam que sua inserção de forma efetiva no currículo da escola brasileira, se deu com a Reforma Francisco Campos, a partir de 1931, no momento em que a escola secundária se tornou parte da escolarização obrigatória no Brasil. Com isso, esse conteúdo passou pela proposição e adoção de determinados manuais didáticos, os quais indicaram o conhecimento histórico a ser ensinado em sala de aula.

Durante as décadas de 1940 e 1950 do século passado, o ensino de História da América ganhou centralidade nos currículos. Constituiu-se, inicialmente, como parte do projeto panamericanista dos Estados Unidos para a América Latina, ao propor uma política de "boa vizinhança" entre os países do continente americano, sob a liderança dos Estados Unidos. Consolidou-se, assim, uma tradição que passou a valorizar a História da América como disciplina autônoma, conforme previsto na Portaria no. 966, de 2 de outubro de 1951. A partir daí, passam a ser produzidos manuais didáticos específicos e autônomos destinados, também, a alunos do ensino fundamental (URBAN; SCHMIDT, 2014).

Bittencourt (2005) identifica uma ausência do estudo da História americana no decorrer da primeira fase do regime militar, com retorno ao final dos anos de 1970 e, sobretudo, nos anos 1980, com novas finalidades. É possível pensarmos em um paradoxo, nesse período, a partir do que registraram Urban e Schmidt (2014), pois ao mesmo tempo em que a historiografia sobre o tema da História da América recebia forte influência da análise econômica e os conteúdos ganhavam uma abordagem mais crítica, as reformas educacionais introduzidas no contexto do regime civil-militar, particularmente com o Parecer ㄲo. 853/71, da Lei no. 5.692/71, extinguiam o ensino de História na escola secundária, mantendoo apenas no 20 grau. Ademais, introduzia a proposta do ensino de Estudos Sociais 
para o ensino de 1o grau. O impacto da inserção dos Estudos Sociais nos currículos escolares é analisado por Bittencourt (1996) nos seguintes termos:

Os conflitos em torno da criação dos Estudos Sociais e de disciplinas de caráter indubitavelmente ideológico como Educação Moral e Cívica e Organização Social e Política do Brasil, exatamente quando a escola era estendida a setores populares até então alijados da escolarização, resultaram, entre outras perdas, na abolição dos estudos da América Latina dos programas escolares. O espaço latino-americano passou a ser tema 'subversivo', segundo os critérios dos técnicos da educação [...] (BITTENCOURT, 1996, p. 208)

É nesse contexto, entendido por Schmidt (2012) como início do período de crise da disciplina História (1971-1985), que surge a necessidade de um controle específico sobre o ensino de História da América pelo governo, que incluiu em seu programa de produção de material didático um manual específico sobre este conteúdo, destinado ao 2 o grau, único espaço em que o ensino de História da América era facultado às escolas. Dessa forma, o próprio Ministério da Educação, por meio da Fename, publicou um caderno especial sobre História da América (URBAN; SCHIMIDT, 2014).

O ensino de temas da História da América, e principalmente da América Latina, que parecia representar uma forma de resistência política durante a ditadura civil-militar não permaneceu nas pautas das aulas, dos livros didáticos e dos vestibulares à medida que o processo de redemocratização se consolidava (SILVA, 2004). Com a publicação dos PCNs, nas décadas de 1990 e 2000, diversos tópicos de História da América voltam a compor o repertório curricular nacional, conforme aponta Bittencourt (2005). Não obstante, em currículos estaduais mais recentes, como o documento produzido pela Secretaria de Estado da Educação do Espírito Santo para o Ensino Médio (ESPÍRITO SANTO, 2009), há escassas referências à História da América. Por isso, concordamos com Bittencourt (1996) quanto ao caráter "acidentado" do ensino da História americana no Brasil, tendo em vista a trajetória descontínua, marcada por sua presença ou ausência nos currículos, o que revela um dos conflitos que envolvem a construção da disciplina História. 
O diálogo com os autores a respeito da presença ou ausência do tema no ensino de História e aos modos como são tratados em coleções didáticas suscita uma série de outras questões que podemos fazer às fontes: que História da América se estudava nos anos 1970? Como? Por quê? Essas mesmas interrogações podem ser feitas ao livro didático mais recente, bem como a programas curriculares de todo o país.

\section{O Cadernos MEC: História da América e o livro História Geral e do Brasil}

O Cadernos MEC: História da América fazia parte de um conjunto maior de publicações cuja primeira edição foi posta em circulação em 1971 pelo Ministério da Educação e Cultura (MEC) e pela Fundação Nacional de Material Escolar $(\text { Fename })^{12}$. A publicação desse manual ocorreu entre a promulgação da primeira Lei de Diretrizes e Bases da Educação (no. 4.024/61) e da Lei da Reforma do ensino de 1 e e 2 o grau (no. 5.692/71). Isso nos leva a considerar, inevitavelmente, as tensões, os debates e as disputas em torno do projeto educacional que se pretendia consolidar no país.

Do ponto de vista da disciplina História, Abud (2008) informa que a partir de 1961, passou-se aos governos estaduais a atribuição de elaborar os programas da escola secundária, o que indica certa descontinuidade da concepção pragmática no sentido de formar cidadãos nos moldes dos interesses do Estado. Essa era uma tendência que havia se fortalecido com as reformas Francisco Campos, de 1931, e Gustavo Capanema, de 1942, as quais "[...] elegeram o estudo da História como instrumento central na educação política e a História do Brasil como fundamental na formação moral e patriótica" (FONSECA, T., 2003). O que se observa com a LDB no. 4.024/61, é um deslocamento do currículo, com a secundarização das ditas humanidades. De uma formação secundária

\footnotetext{
12 Os Cadernos MEC foram produzidos para as disciplinas do ensino básico, por meio da Campanha Nacional de Material de Ensino (CNME), criada em 1956. A partir de 1967, esse material passa a ser publicado pela Fundação Nacional do Material Escolar (Fename), que com a Lei 5692/71, assume centralidade na produção didática. Até 1971, foram seis publicações dos Cadernos MEC: História: três volumes de História do Brasil (1963), para o ensino ginasial (atual anos finais do ensino fundamental), um de História da América (1971) e dois de História Geral (1971) para o ensino colegial (atual ensino médio) (FILGUEIRAS, 2013a).
} 
enciclopédica e humanista, passa-se a um currículo voltado para a tecnização da formação escolar (ABUD, 2008). Como acréscimo, ocorre a redução da carga horária de História no ginasial e a sua descaracterização científica e perda de autonomia disciplinar, no colegial.

Além das mudanças relativas ao lugar ocupado pela disciplina História no currículo, os conteúdos e métodos propostos e sua autonomia como campo epistemológico e disciplinar, a partir da década de 1960, e, sobretudo, nos anos posteriores, durante a ditadura civil-militar, há uma tendência em oferecer aos professores e às escolas "guias", normatizações e orientações/diretrizes para o trabalho pedagógico: “[...] os 'guias' [estão] mais associados ao regime militar, referenciado como elemento de uma prática e um discurso autoritários" (MARTINS, 2007, p. 34).

É nesse contexto que se insere o conjunto de publicações dos Cadernos MEC, que a partir dos anos 1970 passam a orientar o ensino no 2o grau, cuja intenção era apresentar diretrizes aos professores sobre os conteúdos mínimos que deveriam ser ministrados e sobre os métodos mais indicados para esse nível de ensino. Como lembra Filgueiras, especificamente os Cadernos Mec de História do Brasil e de História da América, compunham-se

[...] por vários tipos de exercícios organizados em uma sequência que se complementava e construía o panorama do assunto tratado na unidade. Contudo, como os livros não possuíam conteúdos que poderiam ser consultados para a realização dos exercícios, os alunos precisavam buscar as informações por meio da memória, com o professor ou em outros livros. (FILGUEIRAS, 2013b, p.7)

A autora lembra que essa era uma orientação presente nos Cadernos Mec: História do Brasil 3, elaborado por Arthur Bernardes Weiss, segundo a qual, para tirar proveito dos exercícios do Caderno, seria importante recorrer a outros materiais como: - 'Atlas Histórico Escolar' e 'Atlas Geográfico Escolar', editados pelo Ministério da Educação e Cultura; - livros didáticos de História do Brasil, de História Geral e de Geografia; - dicionário de Português; - lápis preto e de cores, borracha, tesoura e goma" (WEISS, 1968, sem paginação). 
Juntamente com os Cadernos, o MEC publicava o Guia Metodológico ${ }^{13}$, que deveria subsidiar a aplicação das propostas dos Cadernos MEC. Um deles destinava-se, especialmente, aos cadernos de História. Segundo Mimesse:

Os professores que elaboraram este e outros volumes assinalavam a necessidade de uma formação cultural ampla do professor de segundo grau, além de adequada preparação pedagógica. Essa publicação, segundo seus autores, não pretendia guiar os professores nos seus atos, apenas apresentar-lhes um roteiro com orientações. Visava também, à articulação das informações entre os professores das oito primeiras séries e os das três ou quatro séries seguintes [...] trazia considerações sobre a profissionalização nas últimas séries do segundo grau. Continha informações sobre a redação e organização dos objetivos do planejamento escolar, a importância do estudo da História, formas adequadas de se abordar um fato histórico, como escolher o melhor e mais interessante livro didático, quando fazer uso de mapas, Atlas e recursos audiovisuais, como coordenar uma discussão temática em sala, a importância das atividades extraclasses e modelos de avaliações. (MIMESSE, 2009, p. 98-99)

Nesse contexto, o Cadernos MEC: História da América, da autoria de Carlos Delgado de Carvalho e Anna Maria Delgado de Carvalho Riemer ${ }^{14}$ teve como objetivo principal “[...] levar o aluno a situar o Brasil dentro da América”, pois, para os autores, "Conhecer a história de nossos vizinhos ajudará a compreender melhor a nossa história. Não a história isolada de cada país, com enumerações de datas e feitos paralelos, mas o estudo comparativo de sua formação social, política e econômica" (CARVALHO; RIEMER, 1971, p. 8).

A preocupação dos autores com o conhecimento em conjunto e na relação com aquilo que está mais próximo das vidas dos sujeitos, pode ser mais bem compreendida se observarmos os percursos realizados por eles, especialmente, por Carlos Delgado de Carvalho (1884-1980). Desde começos dos anos 1920, era membro do Instituto Histórico e Geográfico Brasileiro (IHGB), professor do Colégio

\footnotetext{
${ }^{13}$ Em tese, as orientações destinavam-se aos usos, pelos professores, dos Cadernos MEC: História Geral; entretanto, pela análise de seu conteúdo, auxiliariam também os usos dos destinados à História da América, pois tratavam de orientações pedagógicas que pretendiam, dentre outros aspectos, garantir uma formação mínima aos professores sobre as exigências provenientes da Lei № 5.692/71, como, por exemplo, a junção das disciplinas de História e Geografia, passando a constituir Estudos Sociais, ao caráter polivalente das escolas públicas, que passa a receber um público antes excluído do processo de escolarização, devido à obrigatoriedade do ensino de 1o grau.

${ }^{14}$ Ambos, naquele período, professores da Faculdade de Filosofia da Universidade Federal do Rio de Janeiro.
} 
Pedro II e estava envolvido com sujeitos e espaços de discussão sobre uma educação renovada, a dizer da Associação Brasileira de Educação (ABE), da qual foi cofundador e membro diretor. ${ }^{15}$

Por conta dessas credenciais, na década seguinte, Delgado de Carvalho aproximou-se de Francisco Campos, primeiro responsável pelo Ministério da Educação e Saúde Pública, recém-criado, e pela condução da Reforma do ensino, realizada em 1931. Participou da elaboração do anteprojeto dessa reforma, assegurando a inclusão de suas concepções de ensino de História na proposta, ${ }^{16}$ as quais aproximavam-se de ideias escolanovistas inspiradas pelas proposições do filósofo norte-americano John Dewey. Na relação com essas ideias, Delgado de Carvalho entendia que

[...] o ensino de História deveria ter um caráter ativo e proporcionar ao aluno a oportunidade de ser sujeito de seu aprendizado. [...] deveria ser capaz de fornecer um conhecimento prático que mostrasse aos estudantes o progresso da humanidade em todos os sentidos. A função do professor de História seria a de guiar as experiências educativas, visando um aprendizado que estabelecesse conexões entre as informações novas e o conhecimento previamente adquirido pelo educando. O ensino, em sua concepção, não deveria apenas promover a memorização e ocupar-se com a preparação para os exames. (VALE, 2011, p. 179)

Esse entendimento perpassava, de acordo com Vale (2011), os programas e as instruções expedidas pelo Ministério, em 1931, e integravam a proposta da obra História Geral, publicada por ele em 1935.17 Na década seguinte, Delgado,

\footnotetext{
${ }^{15}$ Delgado de Carvalho nasceu na Legação do Brasil na França, onde cresceu e estudou Direito e Ciências Políticas. Mais tarde, cursou Sociologia na London School of Economics, na Inglaterra. Chegou ao Brasil aos 22 anos, para produzir sua tese de doutoramento e publicou seu primeiro livro, Geographia do Brasil, em 1913. Tornou-se sócio efetivo do Instituto Histórico e Geográfico Brasileiro (IHGB) em 1921 e, em 1924, participou da fundação da Associação Brasileira de Educação (ABE), que buscava institucionalizar as discussões sobre os problemas da escolarização brasileira. Além disso, tornou-se professor substituto de Inglês do Colégio Pedro II, em 1920, catedrático efetivo de Sociologia daquela escola, em 1927, e vice-diretor do externato do Colégio, em 1930, nomeado por Francisco Campos. Foi, também, o primeiro diretor do Instituto de Pesquisas Educacionais (IPE), fundado em 1933, por Anísio Teixeira, e professor catedrático da cadeira de História Moderna e Contemporânea da Faculdade Nacional de Filosofia da Universidade do Brasil, além de professor da Escola de Professores e de Sociologia do Instituto de Educação. Foi, ainda, signatário do Manifesto dos Pioneiros da Educação Nova, em 1932 (MUNAKATA, 2004; VALE, 2011).

${ }^{16}$ Dentro dessa reforma, criou-se, no ensino secundário, a cadeira de História da Civilização e aboliram-se dos currículos do Colégio Pedro II as cadeiras de História do Brasil e História Universal.

${ }^{17}$ Segundo Vale (2011), o livro Historia Geral, publicado em parceria com Wanda Cardoso, continha documentos textuais e iconográficos e objetivava fomentar o espírito crítico dos estudantes.
} 
antes mais preocupado com a Geografia, passou a lecionar História Moderna e Contemporânea na Universidade do Brasil, ao mesmo tempo em que continuou próximo do meio político, participando da Reforma realizada por Gustavo Capanema, em 1942. Na relação com essa reforma, publicou, respectivamente, nos anos 1945 e 1946, outras duas obras - História da Antiguidade e Idade Média e História Moderna e Contemporânea - baseadas nos propósitos daquela Reforma.

Como informa Vale (2011), a História da América se faz presente entre os conteúdos de História Geral, mas ainda mais no livro História Moderna e Contemporânea, no qual ocupava cerca de 30\% do programa de 2a série, com a intenção de que o estudo do continente ganhasse uma importância maior do que a atribuída anteriormente. Como indica a autora, Delgado entendia que conhecer a História da América era indispensável para estreitar relações entre os países que a compunham. Assim, no livro História Moderna e Contemporânea, buscava estabelecer vínculos entre a história europeia, correntemente abordada na escola, e as sociedades americanas.

O Cadernos Mec: História da América, constituía-se de 188 páginas de exercícios sobre temas que envolvem desde aspectos históricos e geográficos da Ameríndia até as guerras mundiais, passando por temas como: as civilizações ameríndias; a Europa e as Grandes Navegações; conquista e colonização da América, partindo de países europeus e das colônias; administração colonial; economia colonial; independência das Américas e emancipação do Brasil; estruturas políticas e desenvolvimento econômico, incluindo Estados Unidos, Cuba e Canadá; e relações internacionais.

O livro possui uma capa colorida com o mapa da América, opondo, nas duas extremidades inferiores, desenhos que remetem à figura do colonizado (indígena) e do colonizador (europeu), representados como guerreiros, portando armas e lanças e colocados em aparente condição de igualdade. Internamente, o material é ilustrado com mapas, desenhos, quadros, e fotografias em preto e branco e não apresenta indicação de fontes ou referências bibliográficas, uma 
característica de Delgado de Carvalho na produção de seus livros didáticos, como lembra Vale (2011). ${ }^{18}$

O livro didático História geral e do Brasil, por sua vez, foi publicado pela Editora Scipione em 2011, durante a fase de reconstrução da disciplina História (1985 até a atualidade), que tem como marco, a publicação dos PCNs nas décadas de 1990 e 2000 (SCHMIDT, 2012). Seus autores são Claudio Vincentino e Gianpaolo Dorigo. Ambos possuem bacharelado e licenciatura em História pela Universidade de São Paulo, são professores de cursos pré-vestibulares e de ensino médio e autores de obras didáticas.

Hupp (2014) informa que a partir da década de 1990, a elaboração e a produção dos livros didáticos passaram a ser vinculadas indiretamente aos PCNs e diretamente ao PNLD. Embora não se constituam em diretrizes obrigatórias, essas expectativas curriculares oficializadas se tornaram referência para a elaboração dos livros didáticos. Assim, segundo o autor, ao serem relacionados com as orientações dos parâmetros, os manuais adquirem maior legitimidade perante os consumidores e o próprio Estado. Dentre essas orientações advindas dos PCNs, está a inclusão das inovações historiográficas preconizadas pela Nova História, ${ }^{19}$ tais como: a) a ampliação do conceito de fonte; b) a produção da narrativa historiográfica a partir de diferentes temporalidades e; c) a inclusão dos estudantes como sujeitos históricos.

Não podemos negligenciar o fato de que essas produções curriculares nacionais e as obras didáticas pautadas nessas referências ocorrem em meio a um cenário marcado pela lógica neoliberal ${ }^{20}$, o que acaba ressoando em seus

\footnotetext{
18 Como afirma Vale (2011), nos livros e cursos de Delgado de Carvalho não havia iniciação à pesquisa, crítica bibliográfica ou historiográfica. Era um professor mais preocupado em fornecer uma visão global e introdutória sobre os temas de que tratava.

${ }^{19}$ Essa perspectiva historiografia teve início nas décadas de 1920, na França, com a publicação de um periódico, cujo título deu origem ao movimento denominado Escola dos Annales, que tem como representantes da primeira geração Lucien Febre e Marc Bloch. A segunda foi liderada por Fernand Braudel, e a terceira, por Jacques Le Goff, Georges Duby, Roger Chartier, Edward Thompson, dentre outros (BURKE, 1997).

${ }^{20}$ Em síntese, a utopia neoliberal exalta as virtudes abstratas dos mercados, dos prêmios aos mais aptos, da competitividade, da eficiência, das ganâncias, dos direitos de propriedade, e da liberdade de contratação. Critica, em contrapartida, a intervenção estatal e a própria política, taxando-as de perniciosas e ineficientes. Assim se articulam as teses e se prepara o salto à ideia de que os mercados constituem o miolo de um sistema social ideal, automático, o qual garante o bem-estar e a prosperidade (IBARRA, 2011, p. 239-240).
} 
processos de elaboração. A proposta nacional destinada ao Ensino Médio (2000), por exemplo, buscou garantir o propósito de formação ampla, sem ignorar o caráter propedêutico, mas priorizando a formação para o mundo do trabalho. $\mathrm{Na}$ relação com esse contexto, ainda que não tenhamos informações mais específicas sobre a formação e a inserção acadêmica dos autores, é possível identificar em História geral e do Brasil (2011), ecos desses dois movimentos: das inovações historiográficas e do modelo econômico hegemônico pautado na lógica do mercado capitalista.

A seção assessoria pedagógica nos dá pistas da incorporação das inovações historiográficas no conteúdo da obra. Embora os autores anunciem que a coleção da qual essa obra faz parte não se vincula a nenhuma vertente historiográfica em particular, ao explicitarem os princípios sobre os quais se sustenta, notamos seu distanciamento de uma perspectiva positivista e sua aproximação dos pressupostos da Nova História. Dentre os elementos destacados pelos elaboradores estão as seguintes noções: a) o conhecimento como uma construção; b) a impossibilidade de se aprender ou ensinar toda a história; c) a vinculação da história à legitimidade social; d) a variabilidade do saber histórico e a especificidade do saber histórico escolar; e) a participação da história no processo de construção das identidades sociais; e f) o papel da história na formação da cidadania e na politização dos sujeitos. Uma abordagem detalhada nos permitiria a compreensão da especificidade de cada aspecto anunciado, bem como, de seus nexos diretos ou indiretos com os pressupostos da Nova História, porém, os enunciados e as análises posteriores do conteúdo América Espanhola parecem indicar elementos dessa estreita relação.

A tendência neoliberal se presentifica na obra didática também na seção assessoria pedagógica, na qual há uma reprodução da matriz de referência da área de Ciências Humanas e suas Tecnologias, produzidas sob a égide do Ministério da Educação (MINISTÉRIO DA EDUCAÇÃO, sem paginação apud VICENTINO; DORIGO, 2011, p. 9). Esse documento defende a centralidade do processo de ensino e aprendizagem no desenvolvimento de competências e habilidades, bem como na ideia de transferir o protagonismo do processo de ensino e aprendizagem para os educandos. Essas categorias, portanto, 
dimensionam uma formação que possibilite ao estudante se adaptar a diferentes situações de vida e de trabalho. Ademais, na obra didática, a inserção de tais eixos como direcionadores do processo educativo justifica a tentativa de equilibrar "[...] competências e habilidades com conteúdos, procurando conciliar a interpretação, a análise crítica, a discussão de diferentes pontos de vista com a narrativa de processos históricos centrais para a compreensão da nossa vida, como é o caso do século XX e início do século XXI" (VICENTINO; DORIGO, 2011, p. 10).

O livro consta da lista de obras aprovadas pelo PNLD, atendendo à maior parte dos requisitos necessários para que sejam distribuídos pelo MEC. O livro selecionado para esta análise é o volume 2, Manual do Professor ${ }^{21}$, com 336 páginas. Diferente do Cadernos MEC, seu propósito geral é oferecer acesso, para estudantes e professores, aos conteúdos de História Geral e do Brasil. Assim, é dentro de um contexto mais amplo, que envolve Europa, Ásia e África, que localizamos os conteúdos de América.

Como livro que contempla História Geral e História do Brasil, os temas dispostos em seu sumário vão da Europa, considerada (no título) como centro do mundo, passando por temas como: a colonização portuguesa na América; a diáspora africana; as monarquias europeias; as Américas portuguesa, espanhola e inglesa; o apogeu do sistema colonial; o iluminismo; e a independência das colônias inglesas. Num segundo momento, parte-se da Europa, novamente, para a compreensão da constituição do Brasil como país, para em seguida tratar das temáticas: independências da América espanhola; novos projetos políticos oriundos da Europa; relações entre Europa e Estados Unidos no século XIX; constituição do Estado brasileiro; e relações com a África e com a Ásia no século XIX. O volume é finalizado com os temas que envolvem o Segundo Reinado no Brasil.

Publicados com quarenta anos de diferença, os dois manuais diferem muito materialmente: o Cadernos MEC: História da América é um livro menor,

\footnotetext{
${ }^{21}$ O manual do professor contém alguns acréscimos na relação com o livro didático do aluno, como respostas para os exercícios propostos e uma seção intitulada Assessoria pedagógica, diferenciada no livro por páginas amarelas, na qual os autores oferecem comentários sobre os conteúdos, orientações gerais aos professores, textos extras, recursos diversos e sugestões.
} 
com quase metade da quantidade de páginas do livro História geral e do Brasil. Além disso, os recursos visuais utilizados, por motivos óbvios, são limitados em termos de uso de imagem, diagramação, uso das cores etc. O livro História geral e do Brasil é produzido a partir de recursos gráficos mais modernizados: é maior e mais colorido; possui textos, quadros, mapas, gráficos, imagens diversas (obras de arte, fotografias, charges) e muitas cores. Apresenta, ainda, citações diretas e indiretas de autores correntemente lidos no meio acadêmico, como Ronaldo Vainfas, Ciro Flamarion Cardoso, Eric Hobsbawm, Philippe Ariès, Georges Duby, Peter Burke e Marc Ferro.

Com relação à presença do conteúdo História da América nos dois manuais, tomando como ponto de partida os sumários, é possível dizer que ambos se dedicam ao tema, também, de diferentes modos. O Cadernos MEC: História da América traz o conteúdo em seu título e, por isso, ainda que seja um livro mais conciso, dedica-se, com maior afinco, à História da América, especialmente, da América Latina. Em História geral e do Brasil, também é possível ter uma ideia pelo título: um livro com quase 400 páginas dedicadas a um tema tão amplo parece destinar um espaço menor a cada tema.

Além disso, como lembrou Silva (2004), no período da ditadura militar, os temas de América fizeram-se presentes nas escolas e nos manuais didáticos como forma de resistência política. Na década de 1970, em alguns estados que tiveram seus programas reformulados com a Lei № 5.692/71, o ensino da história do continente americano ganha novo espaço, ressaltando as raízes coloniais do continente e de seus traços mais marcantes, sem, no entanto, cair em descrições minuciosas.

\section{A História da América nos manuais didáticos: aproximando a lupa}

Ao nos propormos a uma análise que tome como referência manuais didáticos de História (e se pensarmos de um modo mais amplo, de qualquer outra área), somos levados a refletir sobre os destinatários desses manuais e sobre a finalidade para a qual eles são/foram produzidos. Ao focalizarmos os usos que podem ser feitos deles, pensamos, também, em que tipo de sujeito se pretende formar ou quem se espera que seja o mediador de seu conteúdo. Esses 
são elementos que cabem a um exame que focalize não somente o conteúdo, mas também seu contexto de produção e as finalidades pedagógicas, sociais e políticas que o envolvem.

Para a análise dos manuais consideramos três eixos, especialmente: o conteúdo pedagógico; as funções da iconografia e as narrativas historiográficas predominantes. Mais especificamente, buscamos identificar quais interpretações historiográficas a respeito do continente americano estão presentes nos manuais didáticos analisados e os percursos de aprendizagens propostos para que os estudantes do Ensino Médio se apropriem desses conhecimentos. Para isso, elegemos, nas duas obras, os exercícios ${ }^{22}$ referentes ao conteúdo "América espanhola" - comumente negligenciado nas propostas curriculares. Essa opção justifica-se pelo fato de os Cadernos MEC contemplarem apenas exercícios em sua composição.

Os exercícios que compõem a proposta de Carvalho e Riemer (1971) estão organizados em três seções: a conquista do México, a conquista do Peru e a do Chile, totalizando treze atividades dispostas em quatro páginas. Do ponto de vista do conteúdo pedagógico, e de modo específico, da construção dos exercícios, a maior parte oferece espaços a serem preenchidos pelos estudantes, partindo de enunciados que contenham termos como: enumere, complete, preencha, relacione. Tais termos parecem indicar relações com uma perspectiva pedagógica mais tradicional, que, em linhas gerais, atribui ao estudante atitude passiva diante de uma carga de informações a serem repetidas mecanicamente de forma oral ou por escrito com base no que foi copiado no caderno ou respondido nos exercícios propostos pelos livros (BITTENCOURT, 2009).

Essa orientação também pode ser observada no modo como as atividades são estruturadas, o que, de acordo com Urban e Schmidt (2014, p. 10), "[...] apresenta características de uma determinada didatização do conteúdo, influenciada pela perspectiva do desenvolvimento de habilidades cognitivas

\footnotetext{
22 No caso da obra didática História Geral e do Brasil (2011), para a análise das perspectivas historiográficas, focalizaremos também a seção assessoria pedagógica (exemplar do professor), presente no início do capítulo por conter indicações bibliográficas e orientações didáticas, elementos importantes para a reflexão proposta.
} 
universais". Um exemplo é a primeira atividade do Cadernos MEC: História da América sobre a conquista do México, que propõe quase um exercício de decifração por parte do estudante:

1. F5R13A13D14 C14R19E23 era um aventureiro que veio para Cuba com seu cunhado, o Governador D9E7O V5L1S16U5Z. Em 1518 partiu da ilha de Cuba para o continente contra as ordens do governador.

Numere a coluna da esquerda de acôrdo com a da direita e terá pormenores sôbre a situação:

$$
\begin{aligned}
& 1 \text { - Astecas ( ) inimigos dos astecas que se aliaram a } \\
& \text { Cortez } \\
& \text { ( ) cidade fundada pelo conquistador espanhol } \\
& 2 \text { - Tlascatecas ( ) capital dos astecas } \\
& 3 \text { - Vera Cruz ( ) indígenas que predominam na região } \\
& 4 \text { - Montezuma II ( ) indígenas que predominam na região } \\
& 5 \text { - Tenochtitlán ( ) soberano asteca } \\
& \text { (CARVALHO; RIEMER, 1971, p. 62, grifo dos autores) }
\end{aligned}
$$

A identificação de expressões e nomes de personagens é recorrente no conjunto das atividades desse material, que se caracterizam pela vinculação entre conteúdo e método, associados a uma relação autoritária com a hierarquia de saberes. Esses saberes, que se constituem de nomes de personagens ilustres, datas e fatos, deveriam ser repetidos "de cor" pelos estudantes (BITTENCOURT, 2009). É o que lemos na questão a seguir:

\section{Você sabia que:}

Essa boa acolhida a Cortez e seus homens pode ser explicada por uma lenda?

Diziam os Astecas que seu império acabaria no dia em que o deus da chamado Quetzalcóatl, viesse à terra. Viram pois em Cortez um deus que chegava com soldados brancos, senhores do fogo (armas), e tão velozes como o vento (cavalos).

Os espanhóis porém começaram a fazer todo o tipo de desordens e desatinos para obter ouro, causando uma revolta dos índios. Cortez prende então Montezuma. (CARVALHO; RIEMER, 1971, p. 63, grifo dos autores)

Ainda que no decorrer dos anos 1970, pesquisadores e professores de História considerassem inovações e técnicas educacionais como sinônimos de métodos de ensino inovadores, nessa década coexistiram, em termos de conteúdo, materiais pedagógicos vinculados a diferentes perspectivas, que variavam entre aquela mais tradicional, - como no exercício citado -, mas 
também a relacionada com o ideário escolanovista e as propostas tecnicistas. No que se refere às concepções de História, observam-se feições positivistas e aquelas alinhadas aos pressupostos da Nova História (LUIZ, 2015).

No livro didático de Vicentino e Dorigo (2011), o capítulo sobre América espanhola é organizado juntamente com América inglesa, de modo que os exercícios se subdividem também dessa forma. Especificamente sobre a ocupação da América pelos espanhóis, há três exercícios, dispostos em duas páginas e meia. Nessa proposta, identificamos termos como: pesquise, diferencie, reflita e opine, o que parece indicar vinculação com métodos que atribuem ao estudante o papel de produtor do conhecimento histórico.

Ao abordar A Conquista do México, Vicentino e Dorigo (2011) de forma bem distinta dos Cadernos MEC: História da América, propõem que os estudantes, partindo de uma imagem - o mural pintado pelo mexicano Diego Rivera, em 1951, no Palácio Nacional da Cidade do México -, iniciem as atividades com uma pergunta sobre o pintor:

a) Em livros de Arte, revistas e sites da internet pesquise a biografia de Diego Rivera e informações sobre o movimento muralista no México. Dê especial atenção às relações do artista e do movimento artístico que ele representou com o cenário político mexicano das décadas de 1930 a 1950. (VICENTINO; DORIGO, 2011, p. 119)

Esse primeiro exercício abre um conjunto de sete questões sobre o cenário e as figuras retratadas no mural; entre elas estão os nativos e os espanhóis, a quem os autores sugerem que os estudantes procurem diferenciar, identificando suas expressões e os objetos associados a cada um. A sugestão é que procurem compreender o modo como esses sujeitos, entre os quais também está Fernão Cortez, são imaginados pelo artista.

Os enunciados da atividade indicam ações que exigem dos estudantes muito mais do que a simples localização ou repetição de informações. Pelo contrário, para sua realização torna-se necessário que se lance mão de um repertório de saberes, advindos de leituras de diferentes fontes de pesquisa, inclusive de outras áreas do conhecimento. Além disso, requer análise do 
contexto de produção da imagem, dos dados biográficos do autor e, principalmente, sugere relações entre essas referências para a elaboração do conhecimento histórico. Situando-se há mais de uma década da publicação dos PCNs, observamos vinculação a métodos que facilitem as aprendizagens dos estudantes, propiciando a sua autonomia intelectual (BEZERRA, 2005).

No que envolve as imagens, nos exercícios selecionados, identificamos nexos com distintas abordagens. No Cadernos MEC: História da América, um dos exercícios (Figura 1) propõe, por meio do preenchimento de lacunas, que os estudantes elaborem as legendas para um desenho que reúne o espanhol em seu cavalo e o indígena dócil que se submete ao oferecer presentes, o que parece indicar uma concepção de história pela perspectiva do colonizador como herói e uma abordagem pedagógica mais tradicional.

Figura 1 - Exercício 3, proposto pelo Cadernos-MEC: História da América.

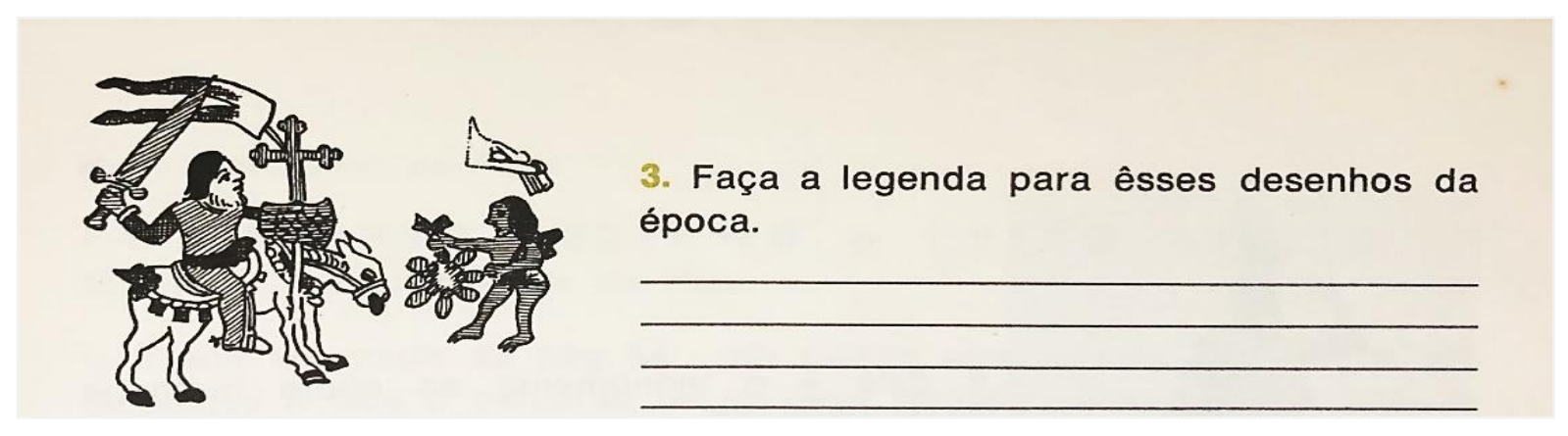

Fonte: Carvalho; Riemer (1971, p. 63).

Sob outra ótica, uma fotografia presente no manual de 1971 (Figura 2) parece buscar diálogos possíveis entre o passado e o presente ou entre tempos e sujeitos diversos. No entanto, no enunciado do exercício, o estudante não é convidado à análise da imagem e do que ela representa. A questão parece referirse apenas ao sustento de uma curiosidade sobre o recebimento de uma estátua do México. As perguntas que poderiam ser feitas são diversas: que estátua é essa? O que ela significa para nós? Por que ela nos foi enviada? 
Figura 2 - Exercício 8, proposto pelos Cadernos-MEC: História da América.

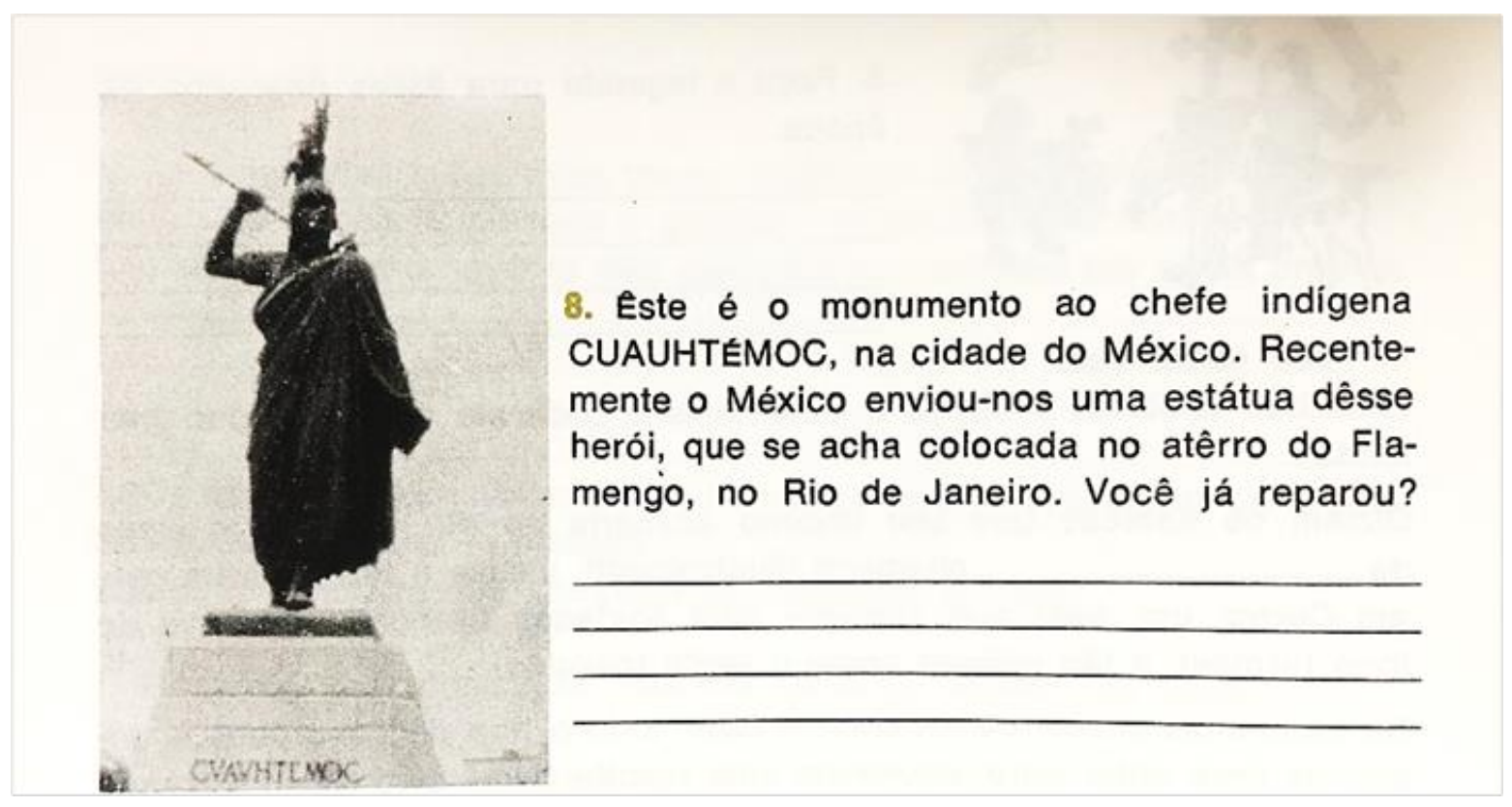

8. Esste é o monumento ao chefe indígena CUAUHTEMOC, na cidade do México. Recentemente o México enviou-nos uma estátua dêsse herói, que se acha colocada no atêrro do Flamengo, no Rio de Janeiro. Você já reparou?

Fonte: Carvalho; Riemer (1971, p. 64).

Por outro lado, é importante salientar que a imagem representa a figura de outro tipo de herói: o indígena e não o espanhol, cuja presença é tão marcante na parte dedicada à conquista da América no Cadernos MEC: História da América. Isso nos leva a entrever a aproximação com uma orientação teórica que questiona a figura do herói cuja imagem é sempre vinculada ao branco e nobre europeu. Esse questionamento indicia uma possível vinculação com o modo como Delgado de Carvalho via os indígenas americanos, aos quais denominava, em conjunto, como civilizações evoluídas. Como lembra Vale (2011), apesar de dedicar nos seus manuais didáticos pouco espaço a esses grupos, ele entendia a importância de seu estudo.

Quatro décadas mais tarde, Vicentino e Dorigo (2011) propõem, em sua obra didática, uma análise iconográfica mais aprofundada da imagem presente nos exercícios anteriormente mencionados - Desembarque espanhol em Vera Cruz, mural de Diego Rivera, de 1951 (Figura 3). 
Figura 3 - Desembarque espanhol em Vera Cruz, mural de Diego Rivera, 1951.

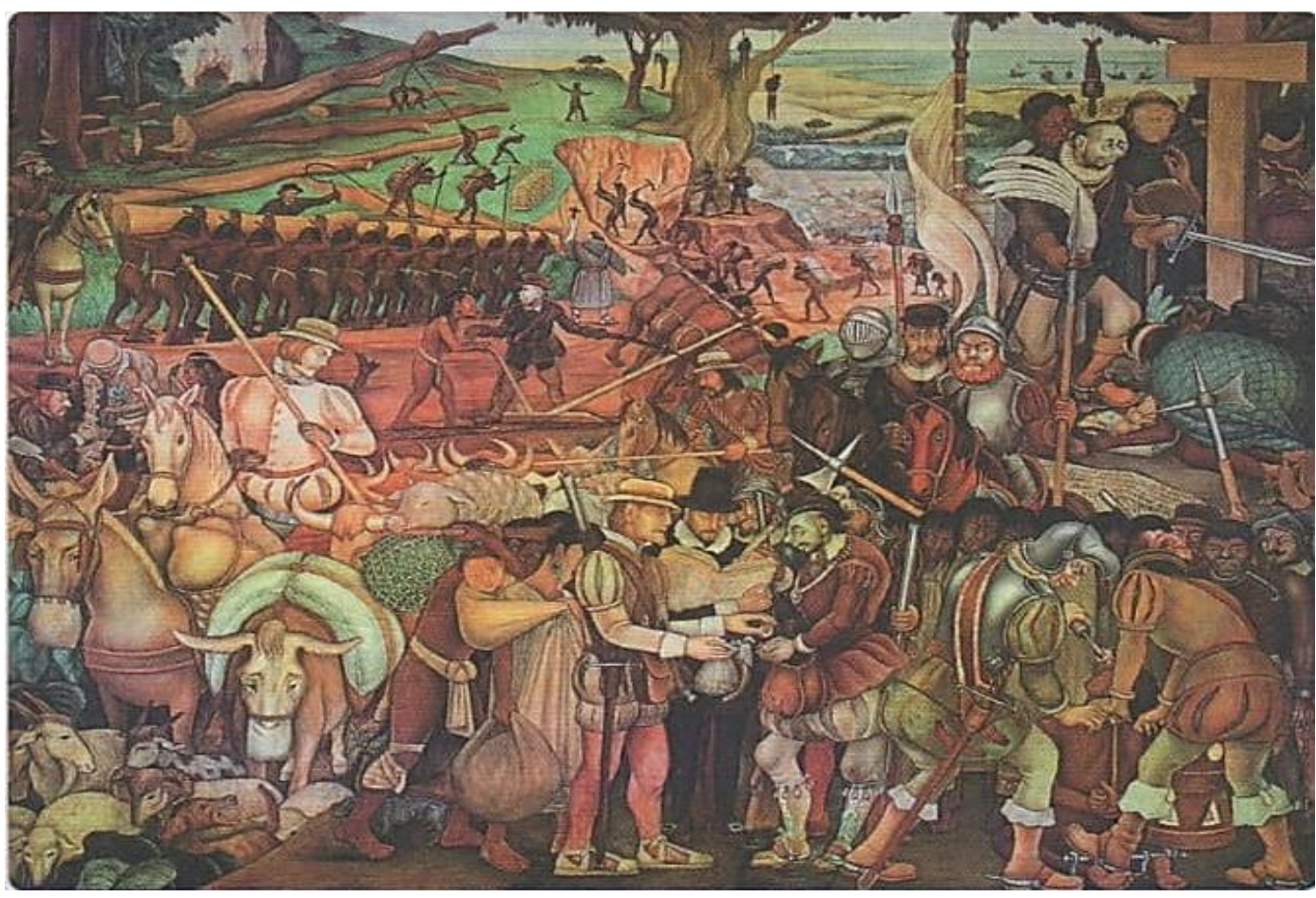

Fonte: Vicentino; Dorigo (2011, p. 119).

A atividade solicita dos estudantes o conhecimento sobre a biografia do pintor - um sujeito cuja leitura da história e do seu tempo, passava pelo seu próprio envolvimento político ${ }^{23}$ - e, por conseguinte, sobre os artefatos culturais, sobre os animais, o ambiente e as feições dos sujeitos da conquista, no modo como são interpretados pelo artista. Esses elementos estão presentes na última questão da série, que exige dos alunos um exame mais atento da imagem:

g) Reflita sobre todos os aspectos que você destacou acima e, com base neles, elabore uma análise de como a conquista espanhola é representada na obra O desembarque dos espanhóis em Vera Cruz, lembrando-se de considerar o contexto em que foi pintada e as propostas defendidas pelo muralismo mexicano. (VICENTINO; DORIGO, 2011, p. 119, grifo dos autores)

\footnotetext{
${ }^{23}$ Segundo Hupp (2014, p. 231), Rivera era membro do Partido Comunista Mexicano e amigo de Trotsky. Tinha consciência da importância social de sua arte. O mural em questão "[...] foi encomendado e posteriormente rejeitado pelos Rockfeller, tradicional família norte-americana de empresários do ramo do petróleo e das finanças e, na primeira metade do século XX, proprietária de uma das maiores fortunas do mundo. A partir desses dados, podemos compreender a crítica de Rivera às mazelas propiciadas pela expansão do capitalismo no final do século XIX e início do século XX, a exaltação dos trabalhadores; o destaque dado aos líderes da Revolução de Outubro e a dualidade sobre quem controla o universo".
} 
As perguntas feitas por Vicentino e Dorigo (2011) parecem se afastar de uma rígida concepção de "verdade histórica", na medida em que convidam os alunos a pensarem sobre a ocupação mexicana na relação com as interpretações feitas por Rivera em seu mural. Ao tratar da utilização de imagens nos livros didáticos, Hupp lembra que:

[...] nossa tarefa requer reflexões sobre representações sobrepostas, pois lidamos com a reprodução de imagens variadas que expressam as representações de seus criadores. Mas, ao serem inseridas nas páginas dos livros didáticos, tais imagens sofrem um processo de manipulação e passam também a expressar as representações de autores e editores, definidas por uma série de fatores, como classe social, faixa etária, visão de mundo, escolaridade, etc. (HUPP, 2014, p. 64)

No Cadernos MEC: História da América a expressão "conquista" e suas derivações: "conquistadores", "conquistados" e "reconquista” chamaram-nos a atenção. Ao longo das treze atividades do material, aparecem doze termos dessa natureza, ao centralizar o espanhol, europeu conquistador, situando, na outra ponta, o indígena, aquele "[...] que passou a figurar apenas como um ser passível de receber a civilização importada da Península Ibérica" (FERNANDES; MORAIS, p. 147). Para os autores - cuja percepção baseia-se nas análises de seis coleções didáticas dos anos 1990 e 2000 -, essa perspectiva historiográfica, presente em tantas obras dessa natureza, parece ter raízes na História acadêmica do século XIX, especialmente, em um artigo de Leopold von Ranke, intitulado As colônias americanas. No entendimento dos autores,

Cercado de fontes consideradas oficiais (e, mais importante, espanholas), o erudito alemão supôs que somente um tipo de escrita era justificável ao ofício do historiador: a científica. Dotado de um método empirista, de uma série de técnicas de detecção de verdade histórica, Ranke, imerso num mundo que ajudava a criar, nacionalista e expansionista, postulou ainda a idéia de uma cultura dominante na empresa colonizadora: a espanhola. (FERNANDES; MORAIS, 2005, p. 147)

Esses elementos identificados no material didático nos levam à reflexão sobre a presença de outras noções, como "exploração" e "violência", observáveis na terceira atividade da seção Conquista do Peru: 


\section{Você sabia que:}

Todos esses quatro personagens foram assassinados?

Ataualpa matou Huáscar e por isso foi morto pelos espanhóis?

Pizarro mandou matar seu sócio Almagro e acabou sendo morto pelo filho deste (1541)?

4. Diante de tantas desinteligências, o governador espanhol tomou conta da região conquistada, criando o Vice-Reinado do Peru (1544).

No mapa da pag. 64 coloque o nome de mais essa região conquistada pelos espanhóis e pinte-a de azul. (CARVALHO; RIEMER, 1971, p. 65, grifo do autor)

Analisar o modo como essas ideias aparecem na proposta didática em questão, não significa negar o massacre nos episódios do século XVI ou as práticas imperialistas sofridas pelo continente latino-americano, inclusive porque se trata de uma questão a ser compreendida, também, em termos populacionais e não apenas naquilo que envolve líderes espanhóis ou indígenas. É preciso, também, como indicam Fernandes e Morais (2005), lançar um olhar que extrapole interpretações tendentes a reduzir a América Latina ao caráter econômico que silencia outras matrizes historiográficas, para além daquele que privilegia a dor, o sofrimento, a exploração e a negação.

A proposta didática de Vicentino e Dorigo (2011) fornece elementos adicionais para a análise. Referimo-nos ao tópico denominado assessoria pedagógica, já que o exemplar de que dispomos destina-se ao professor. Localizamos nessa seção três referências que estão ausentes nos exercícios, mas merecem nossa atenção: O paraíso destruido: brevíssima relação de destruição das Índias, do Frei Bartolomeu de Las Casas (1552), As veias abertas da América Latina, de Eduardo Galeano (1979) e A conquista da América Latina vista pelos índios: relatos Astecas, Maias e Incas, de Miguel Léon Portilla (1984). Nas orientações ao professor recomenda-se que o relato de Las Casas seja utilizado para tratar da violência dos conquistadores sobre os nativos e o texto de Galeano é indicado para caracterizar a economia da América espanhola (VICENTINO; DORIGO, 2011).

Fernandes e Morais (2005, p. 151) apontam a narrativa lascasiana como uma das tradições presentes nos livros didáticos, cuja interpretação considera que o indígena “[...] deveria ser cristão, um servo da igreja e não do Estado espanhol: no lugar da violência física empregada pelos conquistadores, Las Casas 
propôs outro modelo: o católico". Além do destaque para o impulso assassino dos espanhóis, o padre dominicano transforma o indígena em vítima de um processo, incapaz de resistir, portanto, presa fácil para os conquistadores.

A presença dessa referência nas orientações ao professor - e uma transcrição no capítulo para exemplificar a violência dos conquistadores -, sem qualquer detalhamento sobre como trabalhá-la a partir das relações com seu contexto de produção e/ou por meio da análise cruzada com outros documentos, nos leva a pensar sobre as reais possibilidades de o professor explorá-la como fonte em suas aulas. Esse mesmo questionamento pode ser feito com relação ao texto de Galeano. Ao longo do capítulo, os autores da obra transcrevem um fragmento de sua obra para descreverem o funcionamento das mitas de prata de Potosí, cidade atual da Bolívia. Nessa publicação, Eduardo Galeano

[...] faz um traçado histórico para desenvolver uma tese central: a exploração da América Latina, desde o século XV até o XX, provoca pobreza, fome e formas políticas autoritárias em associação ao explorador estrangeiro. A metáfora do título expressa esta tese central: a América Latina é um corpo com as veias abertas, com seu sangue abastecendo 'vampiros' da Europa e dos EUA. (KARNAL, 2001, p. 2)

Um nexo possível entre a obra de Las Casas e a do jornalista uruguaio Eduardo Galeano é expresso por Karnal (2001, p. 8), ao comentá-la trinta anos após sua publicação: "Em síntese, numa retórica maniqueísta tradicional, as personagens exploradas são perfeitamente boas, fadadas à exploração pelo eu lírico onisciente prévio que estabelece seus papéis". Para o autor, nos dois casos, as personagens não têm intenção específica de suscitar análise, mas de comover o leitor, o que foi amplamente explorado pelos dois autores em suas narrativas.

Para além das questões sobre os possíveis usos dessas referências nas aulas pelos professores e os fatores que dificultariam esses usos, importa-nos identificar quais narrativas historiográficas essa proposta pedagógica privilegia e quais visões do continente americano se pretende produzir. A partir das duas referências mencionadas - Las Casas e Galeano -, seria-nos possível dizer que os autores do livro didático estariam reforçando uma postura derrotista? Contribuiriam para consolidar o mito dos vencidos e dos vencedores? 
Esse mito tem como um dos principais representantes Miguel LéonPortilla, terceira referência selecionada na seção assessoria pedagógica. A proposta insere um fragmento da obra A conquista da América Latina vista pelos indios: relatos astecas, maias e incas, na subseção intitulada Pequena seleção de textos. Com o título Os testemunhos Quíchuas da conquista do Império Inca pelos espanhóis, o texto que ocupa uma página das orientações traz um conteúdo que reforça a tese do derrotismo, como lemos no fragmento a seguir:

Teve batalha o legítimo da parte de Cuzco, o bastardo da parte de Quito. Nesta batalha morreram muitos capitães e soldados e se perdeu muitíssima 'hacienda' dos incas e dos templos que até hoje ficaram escondidos em todo este reino e assim foi conquistado e não se defendeu. (PORTILLA, 1984 apud VICENTINO; DORIGO, 2011, p. 109)

O argumento predominante nessa interpretação contribui para negar as vivências e ressaltar as sobrevivências, criando a visão dos vencidos, que, nos termos de Fernandes e Morais (2005, p. 154), produz o "sentimentalismo redentor e o reducionismo técnico: Igreja e laboratório", mostrando uma mistura de ideais de conquista e de imaginário cristão na busca de uma identidade ancestral, um passado indígena e ao mesmo tempo colonizador.

Observamos a partir dessa análise que o modo como os conteúdos, os exercícios, as orientações aos professores e a lista de "coisas para usar" (CARVALHO, 2006) são escolhidos, elaborados e apresentados nos livros didáticos, diz muito sobre as intenções desse material, pois

Os livros didáticos de História, enquanto elementos curriculares de orientação e difusão de saberes históricos a serem escolarizados, produzem e veiculam uma série de representações do passado que educam nossas maneiras de ver, julgar, pensar e posicionar-se perante certos acontecimentos, comportamentos, sujeitos, práticas e relações sociais, tanto do passado como do presente. Por isso, não se trata de narrativas históricas inocentes ou despretenciosas. Como formas de interpretação e produção de sentidos para o passado, tais narrativas são mediadas pela cultura e pelos interesses do presente, sempre marcadas por relações de poder que respondem a leis, padrões e critérios implícitos de controle da educação escolar, sistematizados ao longo da institucionalização dos sistemas públicos de ensino. (OLIVEIRA, 2019, p. 471) 
É preciso considerar, entretanto, que os sujeitos (professores e estudantes) que recebem esse material e os usos que dele fazem são diversos. Para lidar com essas questões mais aprofundadas acerca das intenções, seria preciso supor que o professor tenha algum acesso ao material indicado e, ainda, que sua formação o tenha balizado suficientemente para a autonomia da busca e da leitura crítica das recomendações, das obras e das fontes que lhe são propostas como "coisas para usar".

Como as referências indicadas na seção de orientação ao professor não são contempladas nos exercícios, buscamos identificar as versões historiográficas que os autores privilegiaram em tais propostas. Diferentemente dos Cadernos MEC: História da América, a obra de 2011 apresenta em seus exercícios elementos alinhados à perspectiva da História Nova, ampliando objetos, problemas e temas. São eles: a) análise interna e externa de fontes iconográficas; b) interpretação de textos historiográficos; e c) multiplicidade de abordagens e de fontes históricas.

O primeiro exercício mencionado trata da análise de uma imagem, compondo-se de um conjunto de atividades que permitem o exame interno e externo das fontes pelo estudante, contribuindo para a elaboração do conhecimento histórico. Na segunda atividade, os autores propõem a leitura e interpretação de um fragmento do texto o renascimento ameríndio, de Serge Gruzinski. Num primeiro momento, chamaram-nos a atenção as temáticas abordadas: educação e cultura ameríndia e os impactos que o contato com os espanhóis produziu para essa população. Pela abordagem, notamos diferenças substanciais com relação aos exercícios do material de 1971 e no que envolve as referências indicadas nas orientações ao professor na obra de 2011. Diferentemente da negação, do extermínio e da sobrevivência de povos indígenas, o texto de Gruzinski informa sobre os povos de Tenochtitlán (atual México) antes da chegada dos europeus, destacando a existência do modelo de urbanização, colégios de ensino superior, seus saberes, mitos, rituais e produções artísticas.

As questões subsequentes ao texto proporcionam aos estudantes possibilidades de reflexões, elaborações e aplicações de conceitos históricos já 
consolidados ao longo de suas trajetórias escolares, como cultura, renascença, colonização e humanismo.

O exercício que finaliza a seção destinada à América espanhola propõe a leitura e a análise de uma carta escrita em 1525 por Rodrigo Albernoz, auditor real na Nova Espanha, endereçada ao rei espanhol Carlos I. A partir da leitura desse documento, as questões suscitam análises que podem possibilitar ao estudante compreender: a) o imaginário da época, partindo dos modos como o colonizador representa determinada região indoamericana, local a ser explorado; b) o contexto de produção da fonte, bem como as intenções de quem a produziu (GINZBURG, 2002); e c) noções de historiografia, já que um documento produzido naquele período (carta do século XVI) é tomado como objeto de estudo, permitindo articulações com diferentes tipologias de fontes, como as propostas no primeiro exercício (imagem) e no segundo (texto bibliográfico).

Um olhar para essas fontes, lançado a partir do nosso tempo, terminará por estabelecer entre as obras analisadas comparações que pareçam injustas, a considerar que os dois manuais são fontes situadas no seu tempo. Do ponto de vista historiográfico, por exemplo, o livro de Vicentino e Dorigo (2011) parece se aproximar de uma concepção histórica que hoje privilegiamos: uma história problematizadora, que toma como foco a ampliação do entendimento de fonte, próxima da perspectiva historiográfica proposta por representantes da Nova História, em detrimento de outra, mais focalizada numa cronologia rígida e na figura dos heróis, no geral, homens brancos e europeus. Uma concepção, portanto, mais tradicional e que tem em conta a verdade histórica como pressuposto, à qual, descuidadamente, poderíamos associar o Cadernos MEC: História da América. Assim, ecos da literatura pedagógica e historiográfica de cada época merecem lugar nessa reflexão, embora alguns elementos pareçam ocupar a centralidade nos contornos das obras, outras interpretações são possíveis a partir da leitura cruzada dos elementos que compõem os manuais.

O Cadernos MEC: História da América é atravessado por diferentes perspectivas, especialmente, se considerarmos a trajetória de um de seus autores. A obra parte da abordagem de uma gama de conteúdos relativos à História da América, que inicia pelas civilizações ameríndias, partindo para outros 
lugares e povos do mundo, o que indica alguma vinculação ao ideário escolanovista - no qual Delgado de Carvalho estava mergulhado algumas décadas antes - que apregoava o ensino pelos círculos concêntricos: dos fenômenos mais próximos dos sujeitos aos mais distantes. Além disso, nos anos 1930, o autor primava pela compreensão do aluno como sujeito de sua aprendizagem, pelo fornecimento de um conhecimento prático e, principalmente, que não se baseasse na simples memorização para a realização de exames (VALE, 2011).

Entretanto, o modo como os exercícios são formulados aponta algumas mudanças nas concepções de ensino e de História do autor. Ainda que alguns exercícios indiquem inovação nesse sentido, como lembram Urban e Schmidt (2014, p. 7), ao "[...] introduzir o desenvolvimento de um conjunto de habilidades, tais como caracterizar, comparar, descrever, identificar, entre outras", também é possível observar, pela atenção conferida a fatos e personagens heroicos, pelo uso de expressões como "enumere", "complete" e "preencha" e, ainda, pela ausência de fontes ou referências, uma compreensão pedagógica com elementos tradicionais e uma concepção positivista da História.

Na obra de 2011, essa diversidade de perspectivas se evidencia quando os autores assumem a opção pela centralização das competências e habilidades como eixo organizador dos conteúdos históricos e dos percursos de aprendizagem. A vinculação dessa obra aos pressupostos neoliberais é inegável, de modo que se atribui ao estudante o protagonismo de seus processos de aprendizagem, daí a tentativa de garantir a sua autonomia intelectual, visando a uma redução cada vez maior da mediação do professor no processo educativo.

\section{Considerações finais}

Inspiradas no método regressivo de Bloch (2001), entendemos que é no presente que situamos nossas interrogações e, por conseguinte, a produção de nossas narrativas. As questões aqui levantadas sobre o lugar que o continente americano ocupa no ensino de História, de modo amplo e, nos manuais didáticos, em particular, tomam como referência perguntas sobre como nos enxergamos, atualmente, como sujeitos históricos. A partir disso, optamos por fazer uma 
pausa em nossas reflexões, esperando que estudantes, professores e pesquisadores produzam outras narrativas a respeito da América Latina, por entendermos que é preciso continuar a questionar quais sujeitos têm lugar nas propostas curriculares e quais vozes e faces são ouvidas e visibilizadas. Compreender essas escolhas é crucial para a composição da tapeçaria a ser tecida pelo historiador (GINZBURG, 2007), mas também nos ajuda a pensar o papel dos manuais didáticos, como produtos que são, carregados de intenções.

Como veículo difusor de narrativas historiográficas, o livro didático assume centralidade quando tratamos da História a ser ensinada nas escolas. A serviço do trabalho docente, ele atua como suporte para pensarmos o papel dessa área do conhecimento na constituição de nossa identidade como povo. Tomá-lo como fonte de estudo nos permite investigar uma infinidade de temáticas, dentre as quais focalizamos os modos como manuais didáticos propõem o ensino de um tema historicamente negligenciado nos currículos: a História da América espanhola.

Algumas diferenças precisam ser ressaltadas com relação às duas obras: o livro História Geral e do Brasil dedica um pequeno espaço à temática História da América. Propõe-se como um manual que precisa oferecer uma ampla gama de conteúdos aos estudantes do Ensino Médio e, por isso, o conteúdo em questão termina por ser pouco aprofundado. No caso dos exercícios, a América espanhola reduz-se ao México. Por outro lado, propõe aprofundamento e reflexividade por parte dos alunos e oferece, ao modo de Carvalho (2006), "coisas para usar na sala de aula”, ao indicar fontes, leituras e outras ferramentas aos professores.

No caso do Cadernos MEC: História da América, os exercícios pressupõem um conjunto vasto e variado de atividades sobre os mais diversos temas de América: da Ameríndia às futuras relações internacionais, incluindo os Estados Unidos. De modo geral, a formulação dos exercícios indica relações com perspectivas diversas: ora com uma abordagem ativa, de pressupostos escolanovistas, ora com uma perspectiva pedagógica tradicional, apresentando, ainda, feições positivistas do conhecimento histórico. 
Com base nessas reflexões, entendemos que ao analisar manuais didáticos de diferentes tempos históricos é preciso cuidado para compreender que cada um deles é produto do seu tempo, que foi pensado e produzido para atender demandas escolares específicas, mas também sociais, culturais e de mercado. Como lembra Bittencourt (2005), no caso da História da América, essas propostas são pensadas em função da construção de uma identidade nacional e de um pertencimento regional, que volta à tona, nesse momento, com a proposta da Base Nacional Comum Curricular, que teve sua versão final homologada em 2018, na qual o estabelecimento de relações da História da América com a história da Europa é ponto de debate acalorado em tempos de novas propostas para o ensino de História nas escolas.

\section{Referências}

ABUD, Kátia. Currículos de história e políticas públicas: os programas de história do Brasil na escola secundária. In: BITTENCOURT, Circe Maria Fernandes (org.). O saber histórico na sala de aula. São Paulo: Contexto, 2008. p. 28-41.

BEZERRA, Holien Gonçalves. Conceitos básicos: ensino de história: conteúdos e conceitos básicos. In: KARNAL, Leandro (org.). História na sala de aula: conceitos, práticas e propostas. 3. ed. São Paulo: Contexto, 2005. p. 37-48.

BITTENCOURT, Circe Maria Fernandes. O percurso acidentado do ensino de história da América. In: IOKOI, Zilda Márcia Gricoli; BITTENCOURT, Circe Maria. Educação na América Latina. Rio de Janeiro: Expressão E Cultura; São Paulo: EDUSP, 1996. p. 203-218.

BITTENCOURT, Circe Maria Fernandes. Ensino de história da América: reflexões sobre problemas de identidades. Revista Eletrônica da ANPHLAC, São Paulo, n. 4, p. 5-15, 2005. Disponível em: https://revista.anphlac.org.br/anphlac/article/view/1358. Acesso em: 7 maio 2020.

BITTENCOURT, Circe Maria Fernandes. Ensino de história: fundamentos e métodos. 3. ed. São Paulo: Cortez, 2009. 
BITTENCOURT, Circe Maria Fernandes. Produção didática de história: trajetórias de pesquisas. Revista de História, São Paulo, n. 164, p. 487-516, jan./jun. 2011. Disponível em: https://www.revistas.usp.br/revhistoria/article/view/19206/. Acesso em: 21 abr. 2020.

BLOCH, Marc. Apologia da história ou o ofício do historiador. Rio de Janeiro: Jorge Zahar, 2001.

BRASIL. Lei de Diretrizes e Bases da Educação Nacional. Brasília: Ministério da Educação, 1996. Disponível em:

http://www.planalto.gov.br/ccivil_03/leis//9394.htm. Acesso em: 3 abr. 2020.

BRASIL. Projeto de Lei 7180/2014. Câmara dos deputados. Altera o art. 3o da Lei no 9.394, de 20 de dezembro de 1996, 2014. Disponível em:

<http://www.camara.gov.br/proposicoesWeb/fichadetramitacao?idProposicao=6 06722>. Acesso em: 7 abr. 2020.

BURKE, Peter. A escola dos Annales (1929-1989): a resolução francesa da historiografia. São Paulo: Fundação Editora da Unesp, 1997.

CARVALHO, Carlos Delgado; RIEMER, Ana Maria Delgado de Carvalho. História da América: cadernos MEC. Rio de Janeiro: Ministério da Educação e Cultura/Fundação Nacional de Material Escolar - Fename, 1971.

CARVALHO, Marta Maria Chagas de. A caixa de utensílios e o tratado: modelos pedagógicos, manuais de Pedagogia e práticas de leitura de professores. In: CONGRESSO BRASILEIRO DE HISTÓRIA DA EDUCAÇÃO, 4., 2006, Goiânia. Anais [...]. Goiânia: Sociedade Brasileira de História da Educação, 2006. 1 CD-ROM.

CERTEAU, Michel de. A invenção do cotidiano: 1. artes de fazer. 10. ed. Petrópolis, Rio de Janeiro: Vozes, 2004.

CURY, Carlos Roberto Jamil. Livro didático como assistência ao estudante. Diálogo Educacional, Curitiba, v. 9, n. 26, p. 119-130, jan./abr. 2009. Disponível em:

https://periodicos.pucpr.br/index.php/dialogoeducacional/article/view/3682/359 8. Acesso em: 3 mar. 2020.

ESPÍRITO SANTO. Secretaria da Educação. Ensino médio: área de Ciências Humanas. Secretaria da Educação. Vitória: SEDU, 2009. Disponível em: https://sedu.es.gov.br/Media/sedu/pdf\%20e\%20Arquivos/Curr\%C3\%ADculo/SED U_Curriculo_Basico_Escola_Estadual_(FINAL).pdf. Acesso em: 3 mar. 2019. 
FERNANDES, Luiz Estevam; MORAIS, Marcus Vinícius de. História da América: renovação da história da América. In: KARNAL, Leandro (org.). História na sala de aula: conceitos, práticas e propostas. 3. ed. São Paulo: Contexto, 2005. p. 143162.

FILGUEIRAS, Juliana Miranda. A produção de materiais didáticos pelo MEC: da campanha nacional de material de ensino à fundação nacional de material escolar. Rev. Bras. Hist., São Paulo, v. 33, n. 65, p. 313-335, 2013a. Disponível em: http://repositorio.unifesp.br/handle/11600/7531. Acesso em: 3 mar. 2019.

FILGUEIRAS, Juliana Miranda. Os cadernos MEC de história e matemática: dispositivos pedagógicos e constituição da cultura escolar. In: CONGRESSO BRASILEIRO DE HISTÓRIA DA EDUCAÇÃO, 7., 2013, Cuiabá. Anais [...]. Cuiabá: Sociedade Brasileira de História da Educação, 2013b. 1 CD-ROM.

FONSECA, Thaís Nívea de Lima. História \& ensino de história. Belo Horizonte: Autêntica, 2003.

FONSECA, Selva Guimarães. Didática e prática do ensino de história: experiências, reflexões e aprendizados. Campinas: Papirus, 2003.

GINZBURG, Carlo. Relações de força: história, retórica, prova. São Paulo: Companhia das Letras, 2002.

GINZBURG, Carlo. O fio e os rastros: verdadeiro, falso, fictício. São Paulo: Companhia das Letras, 2007.

HUPP, Wallace Manoel. Leitura de imagens em livros didáticos de história: análise de propostas da produção do saber histórico escolar. Curitiba: Appris, 2014.

IBARRA, David. O neoliberalismo na América Latina. Rev. Econ. Polit., São Paulo, v. 31, n. 2, p. 238-248, jun. 2011. Disponivel em:

https://www.scielo.br/scielo.php?script=sci_arttext\&pid=S010131572011000200004. Acesso em: 3 mar. 2019.

KARNAL, Leandro. As Veias Fechadas da América Latina. [S.l.: s.n.], 2001. Disponível em: https://pt.scribd.com/document/194094303/KARNAL-LeandroVeias-Fechadas-Da-America-Latina. Acesso em: 19 mar. 2020.

LAVILLE, Christian. A guerra das narrativas: debates e ilusões em torno do ensino de história. Revista Brasileira de História, São Paulo, v. 19, n. 38, p. $125-$ 138, 1999. Disponível em:

https://www.scielo.br/scielo.php?script=sci_arttext\&pid=S010201881999000200006. Acesso em: 3 mar. 2019. 
LUIZ, Miriã Lucia. Dentro e fora da ordem: diretrizes curriculares para o ensino de História no Espírito Santo em tempos autoritários (1964-1985). 2015. 205 f. Tese (Doutorado em Educação) - Universidade Federal do Espírito Santo, Vitória, 2015. Disponível em: https://educacao.ufes.br/pt-br/posgraduacao/PPGE/detalhes-da-tese?id=8736. Acesso em: 2 mar. 2019.

MARINHO, Analice Alves. Por uma “América mais americana”: as representações da América espanhola em manuais didáticos para a formação de professores argentinos (1910-1913). Práxis Educativa, Ponta Grossa, v. 8, n. 2, p. 375-396, jul./dez. 2013. Disponível em: https://revistas2.uepg.br/index.php/praxiseducativa/article/view/4857/3628. Acesso em: 2 mar. 2019.

MARTINS, Maria do Carmo. Currículo, cultura e ideologia na ditadura militar brasileira: demarcação do espaço de atuação do professor. In: CERRI, Luis Fernando (org.). O ensino de história e a ditadura militar. 2. ed. Curitiba: Aos Quatro Ventos, 2007. p. 29-46.

MIMESSE, Eliane. A prática pedagógica dos professores de história no uso dos livros didáticos. Revista HISTEDBR On-line, Campinas, n. 35, p. 96-107, set. 2009. Disponível em:

https://periodicos.sbu.unicamp.br/ojs/index.php/histedbr/article/view/8639616. Acesso em: 2 marc. 2019.

MIRANDA, Sonia Regina; LUCA, Tania Regina de. O livro didático de história hoje: um panorama a partir do PNLD. Revista Brasileira de História, São Paulo, v. 24, n. 48, p. 123-144, 2004. Disponível em:

https://www.scielo.br/scielo.php?script=sci_arttext\&pid=S0102-

01882004000200006. Acesso em: 2 mar. 2019.

MORENO, Jean Carlos. História na base nacional comum curricular. Déjà vu e novos dilemas no século XXI. História \& Ensino, Londrina, v. 22, n. 1, p. 7-27, jan./jun. 2016. Disponível em:

http://www.uel.br/revistas/uel/index.php/histensino/article/view/26158. Acesso em: abr. 2019.

MUNAKATA, Kazumi. O livro didático: alguns temas de pesquisa. Revista

Brasileira de História da Educação, Campinas, v. 12, n. 3 (30), p. 179-197, set./dez. 2012. Disponível em:

https://periodicos.uem.br/ojs/index.php/rbhe/article/view/38817. Acesso em: 7 marc. 2019. 
MUNAKATA, Kazumi. Dois manuais de história para professores: histórias de sua produção. Educação e Pesquisa, São Paulo, v. 30, n. 3, p. 513-529, set./dez. 2004. Disponível em: https://www.revistas.usp.br/ep/article/view/27955. Acesso em: 2 abr. 2020.

OLIVEIRA, Susane Rodrigues de. Memórias, subjetivação e educação no tempo presente: como as representações de violência sexual são abordadas nos livros didáticos de História? Tempo e Argumento, Florianópolis, v. 11, n. 28, p. 466-502, set./dez. 2019. Disponível em:

https://revistas.udesc.br/index.php/tempo/article/view/2175180311282019466. Acesso em: 2 mar. 2020.

REIS, Thiago. História da América na BNCC. Associação Nacional de História: Seção Rio de Janeiro, 2015. Disponível em: https://anpuh.org.br/index.php/bncchistoria/item/3129-historia-da-america-e-a-bncc. Acesso em: 19 mar. 2020.

SCHMIDT, Maria Auxiliadora Moreira dos Santos. História do ensino de história no Brasil: uma proposta de periodização. Revista História da Educação, Porto Alegre, v. 16, n. 37, p. 73-91, maio/ago., 2012. Disponível em:

https://seer.ufrgs.br/index.php/asphe/article/view/24245. Acesso em: 19 mar. 2019.

SILVA, Vitória Rodrigues e. O ensino de história da América no Brasil. Diálogos, Maringá: DHI/PPH/UEM, v. 8, n. 2, p. 83-104, 2004. Disponível em: https://periodicos.uem.br/ojs/index.php/Dialogos/article/view/38105. Acesso em: 19 mar. 2020.

\section{UNIVERSIDADE FEDERAL DO ESPÍRITO SANTO (UFES). Projeto pedagógico do} curso de história. Vitória: Colegiado de História, 2018.

URBAN, Ana Claudia; SCHMIDT, Maria Auxiliadora Moreira dos Santos. A construção do código disciplinar da história da América no Brasil, no período da ditadura militar: os "cadernos MEC". Revista de História da UEG, Anápolis, v. 3, n. 1, p. 1-14, jan./jun. 2014. Disponível em:

https://www.revista.ueg.br/index.php/revistahistoria/article/view/2130. Acesso em: 19 mar. 2020.

VALE, Nayara Galeno do. Delgado de Carvalho e o ensino de história: livros didáticos em tempos de reformas educacionais (1931-1946). 2011. 200 f. Dissertação (Mestrado em História Social) - Universidade Federal do Rio de Janeiro, Rio de Janeiro, 2011. Disponível em:

https://minerva.ufrj.br/F/IRR5R823QHIQTM3NBVPQEFLAPRQAGTLPIMSFX7P3C5A DBPVF8X-40896?func=find -

b\&find_code=WRD\&request=Nayara+Galeno+do+Vale\&local_base=UFR01.

Acesso em: 19 mar. 2020. 
VICENTINO, Claudio; DORIGO, Gianpaolo. História geral e do Brasil. São Paulo: Editora Scipione, 2011. v. 2.

WEISS, Arthur Bernardes. História do Brasil: caderno 3. Rio de Janeiro: Ministério da Educação e Cultura: Departamento Nacional de Educação: Campanha Nacional de Material de Ensino, 1963.

Universidade do Estado de Santa Catarina - UDESC

Programa de Pós-Graduação em História - PPGH

Revista Tempo e Argumento Volume 13 - Número 32 - Ano 2021 tempoeargumento@gmail.com 